\title{
NanoSIMS mapping and LA-ICP-MS chemical and U-Th-Pb data in monazite from a xenolith enclosed in andesite (Central Slovakia Volcanic Field)
}

\author{
A. Didier ${ }^{1,3} \cdot$ V. Bosse ${ }^{1} \cdot$ J. Bouloton ${ }^{1} \cdot$ S. Mostefaoui ${ }^{2} \cdot$ M. Viala ${ }^{1} \cdot$ J. L. Paquette ${ }^{1} \cdot$ \\ J. L. Devidal ${ }^{1} \cdot$ R. Duhamel $^{2}$
}

Received: 30 April 2015 / Accepted: 22 October 2015 / Published online: 31 October 2015

(C) Springer-Verlag Berlin Heidelberg 2015

\begin{abstract}
In this study, we use NanoSIMS element and isotope ratio mapping and LA-ICP-MS trace element measurements to elucidate the origins of monazites from a restitic xenolith enclosed in a $13.5 \pm 0.3 \mathrm{Ma}$ andesitic lava (Slovakia). The xenolith/lava interaction is mainly characterized by the growth of a plagioclase-bearing corona around the xenolith and magmatic garnet overgrowths on primary metamorphic garnets within the xenolith. NanoSIMS images $\left({ }^{89} \mathrm{Y},{ }^{139} \mathrm{La},{ }^{208} \mathrm{~Pb},{ }^{232} \mathrm{Th}\right.$ and $\left.{ }^{238} \mathrm{U}\right)$ and trace element analyses indicate that variations of HREE, Y and Eu contents in the monazite are correlated with the resorption and the following overgrowth of garnet and plagioclase in the xenolith. Three domains are distinguished in the monazite grains: the inherited Variscan core at ca. $310 \mathrm{Ma}$ (M1 domain) characterized by low Y and HREE contents and a weak negative Eu anomaly; the inner rim (M2 domain) crystallized during the growth of the plagioclase magmatic corona (large negative Eu anomaly) and the resorption of metamorphic garnet (high HREE and Y
\end{abstract}

Communicated by Franck Poitrasson.

Electronic supplementary material The online version of this article (doi:10.1007/s00410-015-1200-1) contains supplementary material, which is available to authorized users.

\section{A. Didier}

amelie.didier@unil.ch

1 Laboratoire Magmas et Volcans, Université Blaise Pascal - CNRS - IRD, OPGC, 5 Rue Kessler, 63038 Clermont Ferrand, France

2 IMPMC, Muséum National d'Histoire Naturelle, 57 Rue Cuvier, 75005 Paris, France

3 Institut of Earth Sciences, University of Lausanne, Lausanne 1015, Switzerland contents); and the external rim (M3 domain) crystallized during the growth of the plagioclase corona (large negative $\mathrm{Eu}$ anomaly) and during the crystallization of magmatic garnet (low Y, HREE contents) at $\sim 13 \mathrm{Ma}$, i.e. the age of the andesitic lava. The age and chemical zonation of the monazites attest to the preservation of primary monazite in the xenolith despite the interaction with the andesite lava. NanoSIMS imaging provides high-quality sub- $\mu \mathrm{m}$ scale images of the monazite that reveals chemical domains that were not distinguishable on WDS X-ray maps, especially for depleted elements such as $\mathrm{U}$ and $\mathrm{Pb}$. Owing to its small size, the M2 domain could not be accurately dated by the LA-ICP-MS method. However, NanoSIMS isotopic maps reveal that the M2 domain has similar ${ }^{208} \mathrm{~Pb} /{ }^{232} \mathrm{Th}$ isotope ratios to the M3 domain and thus similar ages. These results support the hypothesis that melt-assisted partial dissolution-precipitation in monazite efficiently records chemical and mineralogical changes during xenolith/lava interaction.

Keywords NanoSIMS mapping $\cdot$ Monazite $\cdot$ Trace elements $\cdot$ Melt-assisted dissolution and precipitation . LA-ICP-MS dating

\section{Introduction}

Monazite is an accessory mineral widely used for U-Th$\mathrm{Pb}$ dating of magmatic and metamorphic crustal rocks (e.g. Bingen et al. 1996; Townsend et al. 2001; Rasmussen et al. 2007; Bosse et al. 2009). Because monazite is not sensitive to lead diffusion (Cherniak et al. 2004; Gardés et al. 2006), it is capable of recording successive high-temperature events (Bingen et al. 1996, Berger et al. 2008; Didier et al. 2014). Monazite typically displays chemical heterogeneity and complex zonation (Zhu and 
Fig. 1 Map of the Pannonian basin with the location (red star) of the andesitic lava (SK8-9) outcrop. CSVF Central Slovakia Volcanic Field

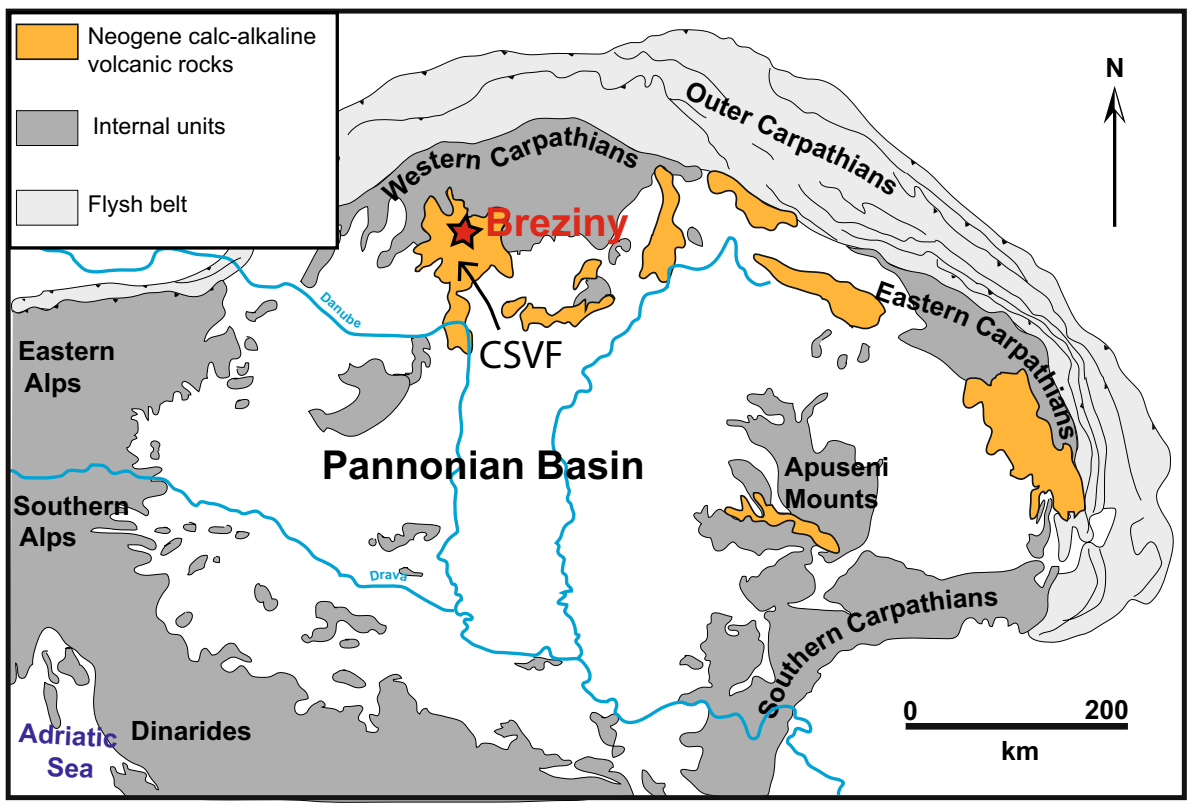

O’Nions 1999; Crowley and Ghent 1999; Foster et al. 2000; Catlos et al. 2002) observed at the $\mu \mathrm{m}$ scale or even at the nm scale (Seydoux-Guillaume et al. 2003). With the development of in situ micro-analysis/dating techniques, investigation of monazite at the sub- $\mu \mathrm{m}$ scale has become a major interest. Recently, field emission electron probe micro-analyser (FEG-EPMA) (Jercinovic et al. 2011), FEG-SEM imaging (Erickson et al. 2014), synchrotron mapping (Appel et al. 2010) and atomprobe tomography (Valley et al. 2014) have been used to study monazite and zircon at the sub- $\mu \mathrm{m}$ scale. This study presents the first attempts of NanoSIMS mapping in monazite.

HREE, $\mathrm{Sr}$ and $\mathrm{Eu}$, present as trace elements in monazite, provide critical information for interpreting monazite ages in the light of the petrological evolution of the rock because they record the chemical reactions occurring contemporaneously with monazite growth. For example, the Eu anomaly and $\mathrm{Sr}$ content of monazite usually reflects the presence or absence of plagioclase in the rock during monazite growth (Krenn and Finger 2007; Rubatto et al. 2013), while the HREE content is highly dependent upon garnet crystallization or resorption (Pyle and Spear 2003; Rubatto et al. 2013).

This study presents NanoSIMS element and isotopic mapping coupled with in situ LA-ICP-MS trace element measurements and $\mathrm{U}-\mathrm{Th}-\mathrm{Pb}$ dating of monazite from a restitic xenolith enclosed in an andesitic lava from the Central Slovakia Volcanic Field. The monazite contains chemical and isotopic micro-domains that reflect sequential mineralogical reactions occurring after the xenolith was incorporated into the magma.

\section{Geological setting and sample location}

The Central Slovakia Volcanic Field (CSVF) is part of a vast volcanic province that extends throughout the Carpatho-Pannonian region (CPR, Fig. 1). Magmatic activity is mainly related to the extension of the intra-Carpathian lithosphere and the formation of the Pannonian basin during the Miocene (Szabó et al. 1992; Harangi et al. 2007; Seghedi 2010). The CSVF is partly located in the western Carpathians, which is composed of Variscan metamorphic and magmatic rocks overprinted by alpine orogenesis. $\mathrm{K}-$ Ar ages (Maluski et al. 1993) indicate that Variscan metamorphism and granite emplacement occurred, respectively, at ca. 340-350 Ma (youngest ages) and 305-335 Ma.

In northern Hungary and central Slovakia, volcanism began with large-volume siliceous calc-alkaline explosive eruptions during the early to middle Miocene (Konecny et al. 1995; Pécskay et al. 2006). This ignimbritic activity was followed by the emplacement of medium- to high-K calc-alkaline andesitic magmas, sometimes garnet-bearing, assumed to be Lower Badenian in age (16.5-16 Ma). The second phase of andesitic volcanism peaked at 14-15 Ma and was principally characterized by the construction of four large stratovolcanoes (Štavnica, Javorie, Vtáčnik and Pol'ana volcanoes). Calc-alkaline volcanism terminated at about $9 \mathrm{Ma}$ and was followed by dispersed alkaline basaltic magmatism that was active from Upper Miocene to Quaternary.

The studied lava sample (SK8), a garnet-bearing andesitec, belonging to the calc-alkaline series, was collected in a quarry near the village of Breziny, located $5 \mathrm{~km}$ south of Zvolen. The sample is derived from an andesitic 
dome that belongs to the lower volcanic unit of the CSVF, the Neresnica Formation. This formation constitutes a discontinuous level that underlies the Štavnica and Javorie volcanoes and is mainly composed of extrusive domes and volcaniclastic rocks that grade into fluvial and limnic sediments of Lower Badenian age (Konecny et al. 1995). This andesite was dated at 15.5-17.9 Ma by the K/Ar wholerock method (Konečný et al. 1969). Recent in situ LA-ICPMS U-Pb results for zircons shielded within magmatic garnets provide a younger age of $13.3 \pm 0.2 \mathrm{Ma}$ (Bouloton and Paquette 2014).

\section{Analytical methods}

\section{NanoSIMS mapping}

Elemental maps were produced with the Cameca NanoSIMS 50 at the Muséum National d'Histoire Naturelle (Paris, France) over the course of two analytical sessions. Analyses were performed on $30-\mu \mathrm{m}$-thick polished thin sections. Samples were coated with $\sim 20 \mathrm{~nm}$ of $\mathrm{Au}$ for the first session and by $\mathrm{C}$ for the second session. Using a focused primary beam $(500 \mathrm{~nm})$ of $\mathrm{O}$ with an intensity of 14-pA, secondary ${ }^{89} \mathrm{Y},{ }^{139} \mathrm{La},{ }^{208} \mathrm{~Pb},{ }^{232} \mathrm{Th}$ and ${ }^{238} \mathrm{U}$ ions were sputtered from pre-sputtered sample surfaces and detected simultaneously (multi-collection mode) by electron-multipliers at a mass-resolving power of $\sim 5000$. At such a mass resolution, isobaric interferences are negligible. For each analysis, a series of 20-30 line-scans were performed. NanoSIMS results were processed using L'Image software (developed by L. Nittler, Carnegie Institution of Washington, Washington DC) to obtain ${ }^{89} \mathrm{Y}$, ${ }^{139} \mathrm{La},{ }^{208} \mathrm{~Pb},{ }^{232} \mathrm{Th}$ and ${ }^{238} \mathrm{U}$ maps, ${ }^{208} \mathrm{~Pb} /{ }^{232} \mathrm{Th}$ ratio maps and RGB maps. Artefacts were observed in the vicinity of the LA-ICP-MS pits and on the edges of some images, the latter resulting from difficulties in scanning the edges of particularly large surfaces (image size $>45 \mu \mathrm{m}$ ). These artefacts typically result in an apparent $\mathrm{La}$ and $\mathrm{Pb}$ increase (for example, left upper and lower edge in Fig. 6b). Highquality images were obtained for $\mathrm{Y}$ and La because of an high ionization efficiency by the $\mathrm{O}$ beam and large contents of these elements in the studied monazites. By comparison, Th is highly abundant (up to $5 \mathrm{wt} \%$ ) yet displays a very low ionization efficiency, resulting in a low signal intensity. NanoSIMS maps were obtained on small and selected portions of the studied monazites with locations indicated in Figs. $6 b, 7 b, 8 b$ and $9 b$ (dashed squares).

\section{EMP analyses}

Quantitative analyses and X-ray maps of monazite were carried out using a Cameca SX100 microprobe (LMV,
Clermont-Ferrand). Operations conditions were for quantitative analyses $15 \mathrm{kV}$ accelerating voltage and $40 \mathrm{nA}$ beam current. Counting times were adjusted to the element concentrations and varied from 10 to $70 \mathrm{~s}$. X-ray lines, background offsets and standards used in this study are derived from the previous study of Montel et al. (1996) except for $\mathrm{Pb}: \mathrm{M} \beta$ line was preferred to overlap $\mathrm{M} \alpha$ line. Compositional images were performed at $15 \mathrm{kV}$ and $200 \mathrm{nA}$ with a focused beam either in beam or in stage scanning mode, depending on map dimensions. The selected X-ray lines were $\mathrm{CaK} \alpha, \mathrm{YL} \alpha, \mathrm{LaL} \alpha, \mathrm{ThM} \alpha$ and $\mathrm{UM} \beta$.

\section{U-Th-Pb LA-ICP-MS dating}

$\mathrm{U}-\mathrm{Th}-\mathrm{Pb}$ isotopic analyses of monazite in thin section were performed by laser ablation inductively coupled plasma mass spectrometer (LA-ICPMS) at the Laboratoire Magmas et Volcans (LMV), Clermont-Ferrand (France). The ablation is performed using a Resonetics Resolution M-50E system equipped with an ultra-short pulse ( $<4 \mathrm{~ns})$ ATL excimer $193 \mathrm{~nm}$ wavelength laser. This laser system is coupled with Agilent 7500 cs ICP-MS equipped with a pumping system to enhance the sensitivity. Spot diameter $11 \mu \mathrm{m}$ was used with a $1-\mathrm{Hz}$ repetition rate and a fluence of $15 \mathrm{~J} / \mathrm{cm}^{2}$. Monazite grains were analysed on polished thin sections after electron microprobe work. Ablated material is transported using a helium flux and then mixed with nitrogen and argon before being injected into the plasma source. Analytical procedures for monazite dating are reported in detail in Didier et al. (2013) and Paquette and Tiepolo (2007). Following isotopes ${ }^{204}(\mathrm{~Pb}+\mathrm{Hg}),{ }^{206} \mathrm{~Pb}$, ${ }^{207} \mathrm{~Pb},{ }^{208} \mathrm{~Pb},{ }^{232} \mathrm{Th}$ and ${ }^{238} \mathrm{U}$ were acquired. Data disturbed by inclusions, fractures or age mixing (between different areas of a single grain) were not taken into account for calculation. The occurrence of common $\mathrm{Pb}$ in the sample can be monitored by the evolution of the signal intensity, but no common $\mathrm{Pb}$ correction was applied owing to the large isobaric interference from $\mathrm{Hg}$. Data were corrected for $\mathrm{U}-\mathrm{Pb}$ and $\mathrm{Th}-\mathrm{Pb}$ fractionation occurring during laser sampling and for instrumental mass discrimination by standard bracketing with repeated measurements of the Moacyr monazite standard (Cruz et al. 1996; SeydouxGuillaume et al. 2002; Gasquet et al. 2010; Fletcher et al. 2010 "the French monazite"). Accuracy and precision of the non-matrix-matched standardization were checked by repeated analyses of the Manangoutry monazite, which yield a weighted mean ${ }^{208} \mathrm{~Pb} /{ }^{232} \mathrm{Th}$ age of $554 \pm 5 \mathrm{Ma}$ (MSWD $=1.9$ ); see supplementary material S1. This is in agreement with ID-TIMS analyses of the Manangoutry monazite (Paquette and Tiepolo 2007). Data reduction was carried out with the GLITTER ${ }^{\circledR}$ software package (van Achterberg et al. 2001). 


\section{Trace elements measurements by LA-ICP-MS}

Trace elements (Sr, Eu, HREE) analyses were carried out with LA-ICP-MS at the Laboratoire Magmas et Volcans (Clermont-Ferrand, France). For monazite, Moacyr standard (Seydoux-Guillaume et al. 2002; Gasquet et al. 2010) was used as external standard to avoid chemical fractionation observed with NIST610 for U and Pb. Moacyr composition was determined from both EMP and LA-ICP-MS analyses. $\mathrm{La}, \mathrm{U}$ and $\mathrm{Pb}$ contents were measured by EMP, whereas Sr, Y, REE and Th concentrations were derived from LA-ICP-MS analyses using La as internal standard and NIST 610 for external calibration (see supplementary material S2). During monazite analytical session, the synthetic glass NIST610 and the Manangoutry Monazite (Paquette and Tiepolo 2007) were used as secondary standards. The spot size was $11 \mu \mathrm{m}$, with a repetition rate of $1 \mathrm{~Hz}$. A good agreement is observed between EMP and LA-ICP-MS analyses as long as concentrations are well above the detection limit. Garnet and plagioclase analyses were performed with a spot size of $58 \mu \mathrm{m}$ and a repetition rate of $3 \mathrm{~Hz}$ and a fluence of $13 \mathrm{~J} / \mathrm{cm}^{2}$. External calibration was performed relative to NIST 612 glass. Internal standards were $\mathrm{Fe}$ for garnet and $\mathrm{Ca}$ for plagioclase. All data reduction was carried out with the GLITTER ${ }^{\circledR}$ software package (Macquarie Research Ltd 2001; van Achterberg et al. 2001).

\section{Petrography and mineral chemistry}

\section{The Andesitic lava}

Whole-rock major element data for the SK8 lava are given in supplementary material Table S3. According to the classification scheme of Gill (1981), it is a medium-K, calcalkaline andesite and, as shown by its A/CNK value (0.98), is nearly alumina-saturated. Sample SK8 is highly crystalline with more than $40 \%$ phenocrysts by volume set in a hyalopilitic groundmass. Plagioclase and hornblende are nearly identical in size (up to $8-10 \mathrm{~mm}$ ) and abundance (20-25 vol\% plagioclase and $15-20$ vol\% hornblende). Garnet $\left(\mathrm{Alm}_{63} \mathrm{Grs}_{11} \mathrm{Sps}_{5} \operatorname{Prp}_{18}\right)$ is commonly larger than any other phase in the rock (up to $15 \mathrm{~mm}$ ) and has a $\mathrm{CaO}$ content of $\sim 5 \mathrm{wt} \%$. It is homogeneously distributed but comprises only about $1 \%$ of the rock by volume.

\section{The Garnet-bearing Al-rich xenoliths}

Xenoliths are not abundant in this andesitic lava and appear in the sample as poorly foliated dark fragments (Fig. 2a), a few centimetres in length surrounded by a light-coloured external magmatic corona composed of plagioclase, hornblende and garnet (Fig. 2b, d, e). It is characterized by a low $\mathrm{SiO}_{2}$ content $\left(41.1 \mathrm{wt} \%\right.$ ) and a high $\mathrm{Al}_{2} \mathrm{O}_{3}$ content (26.9 wt\%) suggesting restitic origin (supplementary table $\mathrm{S} 3$ for bulk-rock major elements in the xenolith).

\section{Petrography and mineralogy of the SK8-9 xenolith}

The width of the external magmatic corona varies from a thin overgrowth (few hundreds of $\mu \mathrm{m}$ ), characterized by the development of euhedral faces of plagioclase against the groundmass, to an accumulation of interlocked euhedral plagioclase $\left(\mathrm{An}_{65-80}\right)$ up to $2 \mathrm{~mm}$ in size, containing interstitial groundmass. Euhedral brown hornblende is commonly associated with the plagioclase and may be associated with orthopyroxene. Garnet displays a strong chemical zoning (Fig. 3a): the grossular-poor core $\left(\mathrm{Alm}_{73} \mathrm{Grs}_{2} \mathrm{Sps}_{5} \mathrm{Prp}_{17} ; \mathrm{CaO} \leq 2 \mathrm{wt} \%\right)$ is partially resorbed and surrounded by a 100 - to $700-\mu \mathrm{m}$-wide rim with a composition $\left(\mathrm{Alm}_{62} \mathrm{Grs}_{10} \mathrm{Sps}_{5} \mathrm{Prp}_{20} ; \mathrm{CaO}\right.$ up to $\left.5.5 \mathrm{wt} \%\right)$ similar to the garnet megacrysts in the andesitic lava, suggesting a magmatic origin. The core itself shows chemical zoning, in particular with respect to the HREE that are depleted in the internal zone relative to the external zone (Fig. 4a). The garnet rim has a nearly flat HREE pattern $(\mathrm{Dy} / \mathrm{Yb} \sim 1)$ and a lower Eu anomaly $\left(\mathrm{Eu}_{\mathrm{N}} / \mathrm{Eu}^{*} \sim 0.4\right)$ relative to the garnet core $\left(\mathrm{Eu}_{\mathrm{N}} / \mathrm{Eu}^{*} \sim 0.1\right)$.

The xenolith itself is fine- to medium-grained and consists primarily of plagioclase and biotite, and associated with abundant fibrolitic sillimanite and rare garnet (Fig. 2b). Spinel is a minor constituent and may be associated with corundum. Accessory minerals are ilmenite, apatite and zircon, along with subhedral crystals of monazite up to $400 \mu \mathrm{m}$ in size. Quartz and K-feldspar are absent. Biotite flakes and fibrolite folia define a weak foliation and are statically overgrown by coarse-grained plagioclase $\left(\mathrm{An}_{48-54}\right)$. Biotite $\left(\mathrm{Mg}^{*}=0.51-0.59, \mathrm{TiO}_{2}\right.$ up to $4.5 \mathrm{wt} \%$ ) has generally embayed rims and contains oxidized spinel grains indicating that it is unstable, whereas plagioclase encloses abundant sillimanite needles. Garnet is euhedral and seems in textural equilibrium with plagioclase (Fig. 3b). It displays the same zoning pattern as garnet from the external corona (rim: $\mathrm{Alm}_{61} \mathrm{Grs}_{12} \mathrm{Sps}_{8} \operatorname{Prp}_{16}$, core: $\mathrm{Alm}_{69} \mathrm{Grs}_{3} \mathrm{Sps}_{5} \mathrm{Prp}_{22}$ ), with a smaller magmatic rim $(70 \mu \mathrm{m})$. Because of the narrow rim of the garnet in the xenolith, trace elements analyses could not be performed.

The size and habit of the minerals demonstrate that the corona is magmatic and partly grew at the expense of the restitic xenolith. The similar chemical composition between garnet megacrysts in the lava and garnet rims in the xenolith shows that the latter is magmatic and crystallized during xenolith/andesite interaction. 
Fig. 2 a Photomicrographs and interpretative sketch of a thin section of the xenolith enclosed in the andesitic lava SK8-9. The empty square on the map indicates the location of the photomicrograph shown in b. c, $\mathbf{d}$ Photomicrographs of garnet, respectively, located in the magmatic corona and in the restitic xenolith. Abbreviations according to Kretz 1983
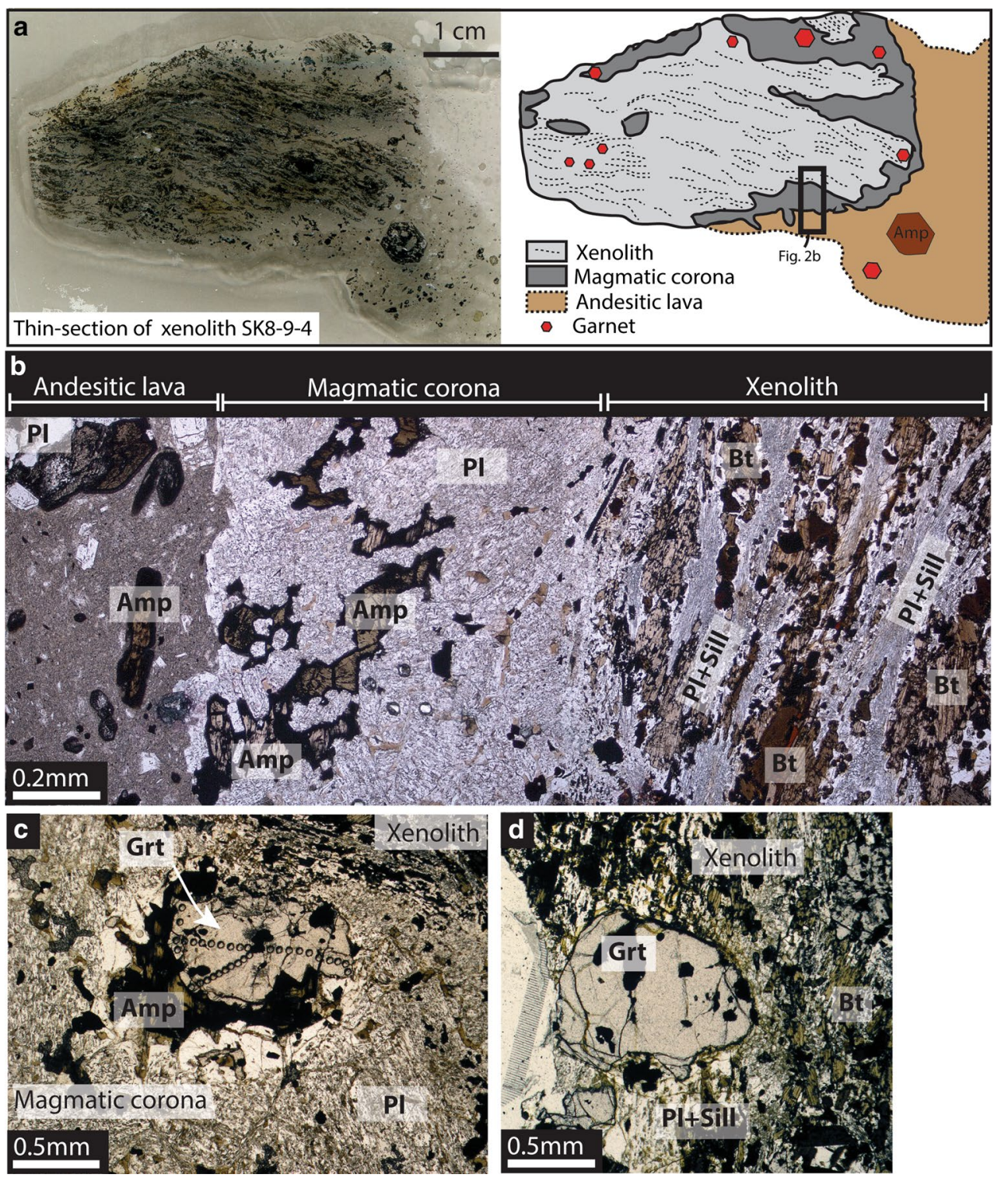

\section{Xenolith origin and conditions of enclavement}

The chemical characteristics of the xenoliths (low $\mathrm{SiO}_{2}$, high $\mathrm{Al}_{2} \mathrm{O}_{3}$ ) suggest a restitic origin after extraction of an acidic melt derived from a gneissic parent rock. The mineralogy shows that melting was inhibited by quartz exhaustion, leading to the residual assemblage plagioclase + biotite. The precise nature of the original material is currently unknown. No melt inclusion is present in any mineral in the core of the xenolith, and no film of glass, either fresh or devitrified, was found along the grain boundaries. This observation suggests that melting predates the enclavement and that the fragments of rocks incorporated in the andesitic magma were already restites. These melt-depleted crustal rocks may either result from (1) local partial melting of the lower crust in the immediate vicinity of deep-seated basaltic intrusions at a preliminary stage of the Neogene volcanic event, or (2) came from an older migmatitic complex of regional extension, related to a previous orogeny (Variscan or older).

An estimatation of pressure-temperature of interaction may be theoretically obtained from the garnet + plagioclase + hornblende \pm orthopyroxene association observed in the magmatic corona, using garnet-orthopyroxene or garnet-hornblende $\mathrm{Fe}-\mathrm{Mg}$ exchange thermometry coupled with garnet-plagioclase-orthopyroxene-quartz or garnet-plagioclase-hornblende-quartz barometers. Temperatures calculated using orthopyroxene are more satisfactory, yet too low for a magmatic environment $\left(650-750{ }^{\circ} \mathrm{C}\right.$ at a reference pressure of $1 \mathrm{GPa}$, depending on the calibrations used). A more realistic estimate may be obtained using the hornblende-plagioclase 

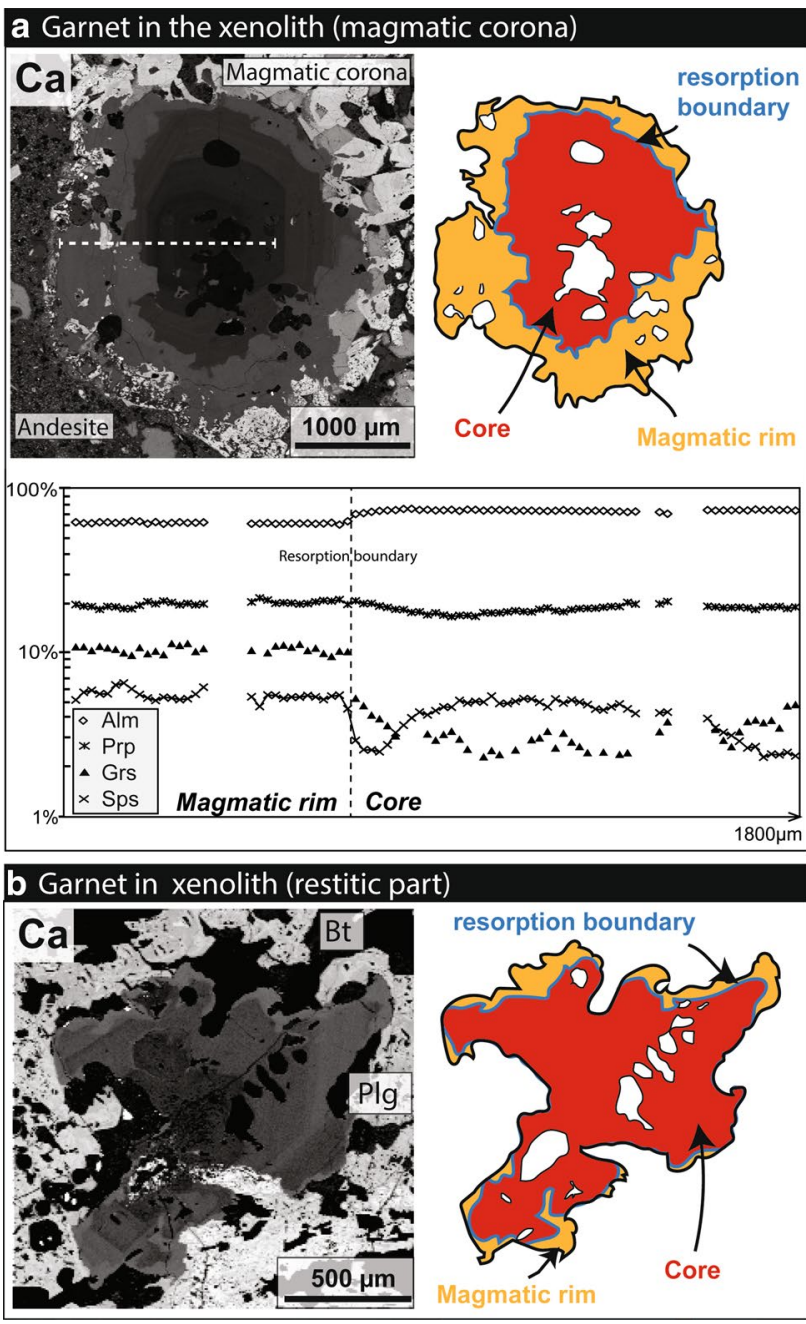

Fig. 3 Ca-map and interpretive sketch of a garnet located in the magmatic corona (a) and in the restitic xenolith (b). a Chemical zoning profile in a garnet from the magmatic corona. The core is partially resorbed and surrounded by a magmatic rim more enriched in Ca. Craters in $\mathbf{b}$ correspond to laser ablation pits

thermometer. Because the exchange vector $(\mathrm{NaSi}-\mathrm{CaAl})$ involves breaking of the silica tetrahedra, the plagioclase-hornblende thermometer has a closure temperature significantly higher than that of $\mathrm{Fe}-\mathrm{Mg}$ exchange reactions and is therefore believed to give more representative magmatic temperatures. Using the equilibrium edenite + albite $=$ richterite + anorthite, specifically designed for silica-undersaturated rocks (Holland and Blundy 1994), temperatures calculated for instance at a fixed pressure of $0.8-1 \mathrm{GPa}$ are in the range $900-950{ }^{\circ} \mathrm{C}$. This value broadly corresponds to the upper limit of hornblende stability in acid andesitic melts as deduced from phase equilibria studies (Eggler 1972).

Maximum pressure conditions may be estimated using the garnet-orthopyroxene-silica-plagioclase (GOSP) equilibrium. Commonly used for barometric purposes in granulitic parageneses, this equilibrium requires the presence of quartz to give significant pressure estimates. However, in the absence of quartz (i.e. $a_{\mathrm{SiO}_{2}}<1$ ) it still may provide an upper limit (maximum pressure conditions). Kriegsman and Hensen (1998) for instance have discussed the consequences of lowering the activity of $\mathrm{SiO}_{2}$ on similar pressure-sensitive equilibria in solid and partially molten systems. We assume therefore that application of the GOSP barometer to the garnet-orthopyroxene-plagioclase association of the magmatic corona allows us to infer the maximum depth of enclavement. Because the analysed garnets and orthopyroxenes contain more than 60 and $50 \%$ almandine and ferrosilite components, respectively, it is assumed that pressures determined from $\mathrm{Fe}$ calibrations should be more accurate. Accordingly, the Fe calibrations of Bohlen et al. (1983), Perkins and Chipera (1985) and Moecher et al. (1988) were used: at $900{ }^{\circ} \mathrm{C}$, the calculated pressures range from 0.8 to $1 \mathrm{GPa}$.

Average $\mathrm{P}$ and $\mathrm{T}$ estimates from the mineral assemblage (Opx-Amph-Plag-Grt) in the external corona were determined using the software package THERMOCALC (Powell and Holland 1994; Holland and Powell 2001). Estimated P-T conditions of equilibration is around 800 $850^{\circ} \mathrm{C}$ and $10-11 \mathrm{kbars}$ for a low water activity $(0.2-0.3)$. These results suggest that the minimum pressure conditions of crystallization of the magmatic rims of garnet are not less than $0.8 \mathrm{GPa}$, a value that is confronted by recent experiments of Alonso-Perez et al. (2009). Given that garnet magmatic rims in the corona have the same chemical composition than garnet megacrysts in the andesite and therefore crystallized most probably in the same conditions, we believe that comparison with these experiments is likely. These authors performed experiments on an andesitic composition (54 wt $\left.\% \mathrm{SiO}_{2}\right)$ at pressures ranging from 0.8 to $1.2 \mathrm{GPa}$, temperatures between 800 and $1000{ }^{\circ} \mathrm{C}$, variable $\mathrm{H}_{2} \mathrm{O}$ contents and $f \mathrm{O}_{2}$ around QFM. The lower pressure limit of garnet stability in the temperature range concerned $\left(900-950{ }^{\circ} \mathrm{C}\right)$ is $0.8 \mathrm{GPa}$, as indicated by the very low modal content of garnet $(0.1-1.3 \%)$ that coexists in these conditions with hornblende, plagioclase and melt. Experimental garnet compositions are significantly more calcic than those recorded in the natural garnets studied here ( $10 \mathrm{wt} \% \mathrm{CaO}$ vs. $5 \mathrm{wt} \%)$, but this discrepancy may be at least partly attributed to the higher $\mathrm{CaO}$ content of the starting material. In summary, it is thus proposed that monazite recrystallization probably occurred at $\mathrm{T}-\mathrm{P}$ conditions close to $900-950{ }^{\circ} \mathrm{C}$ and $0.8-1.2 \mathrm{GPa}$.

\section{Textural and compositional characteristics of monazite}

Monazite is present in both portions of the xenolith, abundant in the restitic part and rare in the external magmatic 


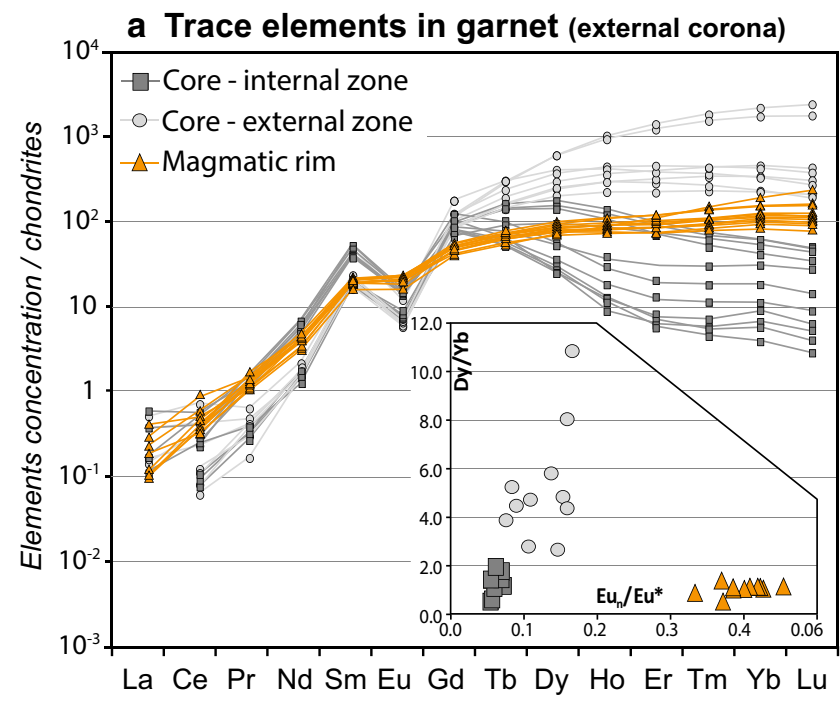

b Trace elements in plagioclase

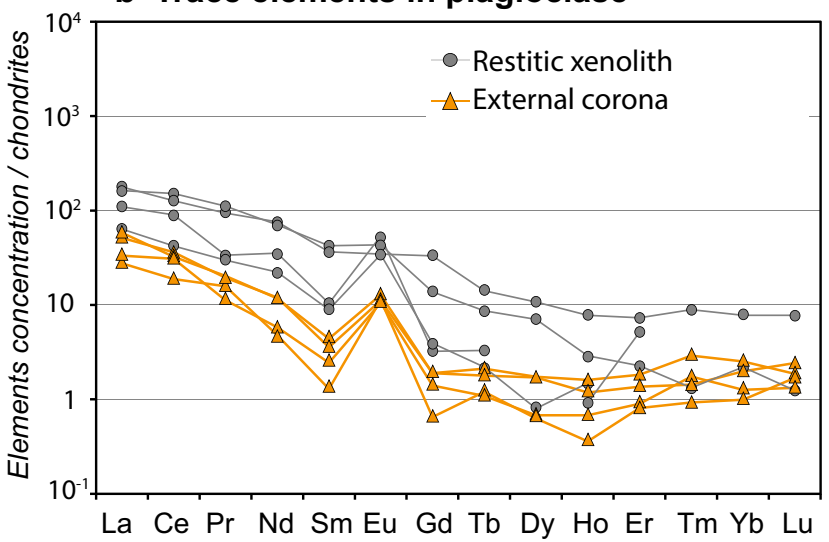

Fig. 4 a Trace element patterns and $\mathrm{Yb} / \mathrm{Dy}$ versus $\mathrm{Eu}_{\mathrm{n}} / \mathrm{Eu}^{*}$ diagram for the core and the magmatic rim of a garnet in the magmatic corona. b Trace elements patterns for plagioclases in the restitic xenolith and in the magmatic corona. c Trace elements patterns and $\mathrm{Lu} / \mathrm{Sr}$ versus $\mathrm{Eu}_{\mathrm{n}} / \mathrm{Eu}^{*}$ diagram for the three monazite domains. The $\mathrm{Er}$ and

corona. In the restitic part, monazite grains $(50-400 \mu \mathrm{m})$ are commonly associated with biotite, sillimanite and plagioclase (Fig. 5a, b). Grains have a variety of habits (elongated; rounded; angular) and rims may be embayed (Fig. 5a, b). Most of the monazites occur as independent grains, but clusters of monazite are also present within plagioclase (Fig. 5d). Some monazite crystals also contain apatite inclusions $(<15 \mu \mathrm{m}$ large, Fig. 5e). In the magmatic corona, monazite is rare and consistently surrounded by apatite (Fig. 5f).

$\mathrm{Y}$ and $\mathrm{Ca}$ (Figs. 6a, 7a, 8a, 9a), Sr, Eu and HREE contents (Fig. 4c) show strong variations within all single monazite grains (Table 1). Three chemical domains have been distinguished based on these variations: M1, M2 and M3 described below. Within a single grain, three distinct

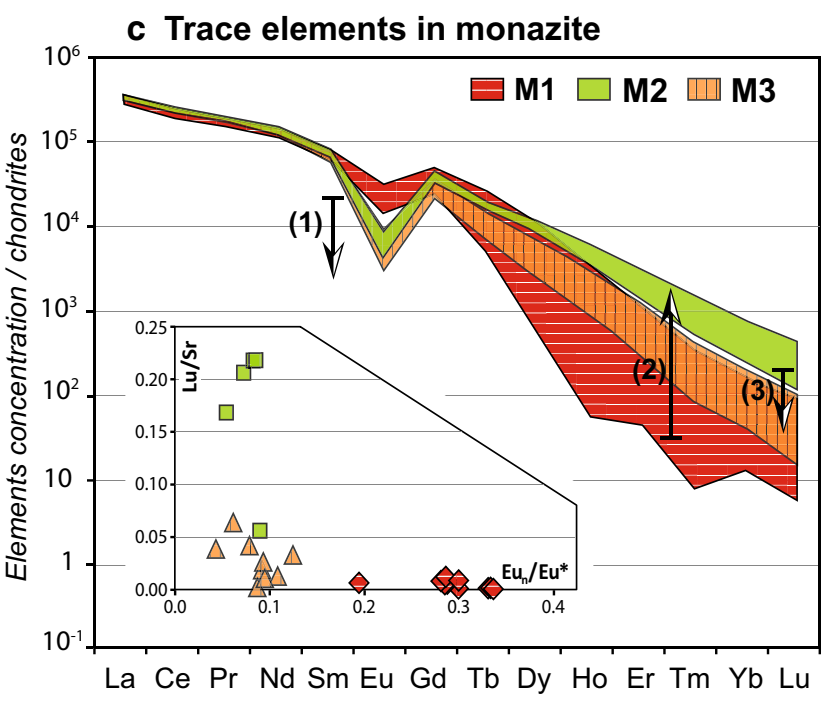

d Partitioning coefficients

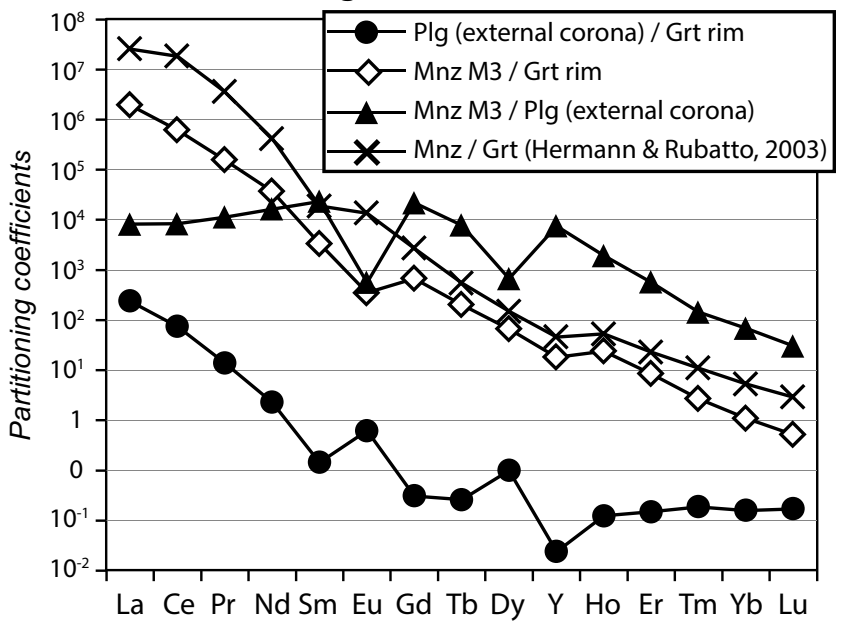

$\mathrm{Yb}$ increasing for the M1 domain lower boundary could correspond to analytical artefacts. $\mathbf{d}$ Trace element partitioning between monazite M3 and the magmatic garnet rim; M3 monazite and plagioclase from external corona; plagioclase from the external corona and the magmatic garnet rim

configurations are defined by the distribution of these domains: (1) concentric zoning (Figs. 6a, 7a) with a core (M1), an internal rim (M2) and an external rim (M3); (2) patchy zoning (Fig. 8a) with only M2 and M3 domains; or (3) no zoning (Fig. 5f), composed of the M1 domain and only observed in monazites from the magmatic corona.

\section{The M1 domain}

The M1 domain occurs systematically in the cores of monazites displaying concentric zoning (Fig. 6a), and this domain constitutes the entire grain in monazites surrounded by apatite in the magmatic corona (Fig. 5f). The M1 domain (Table 2) is characterized by a very 


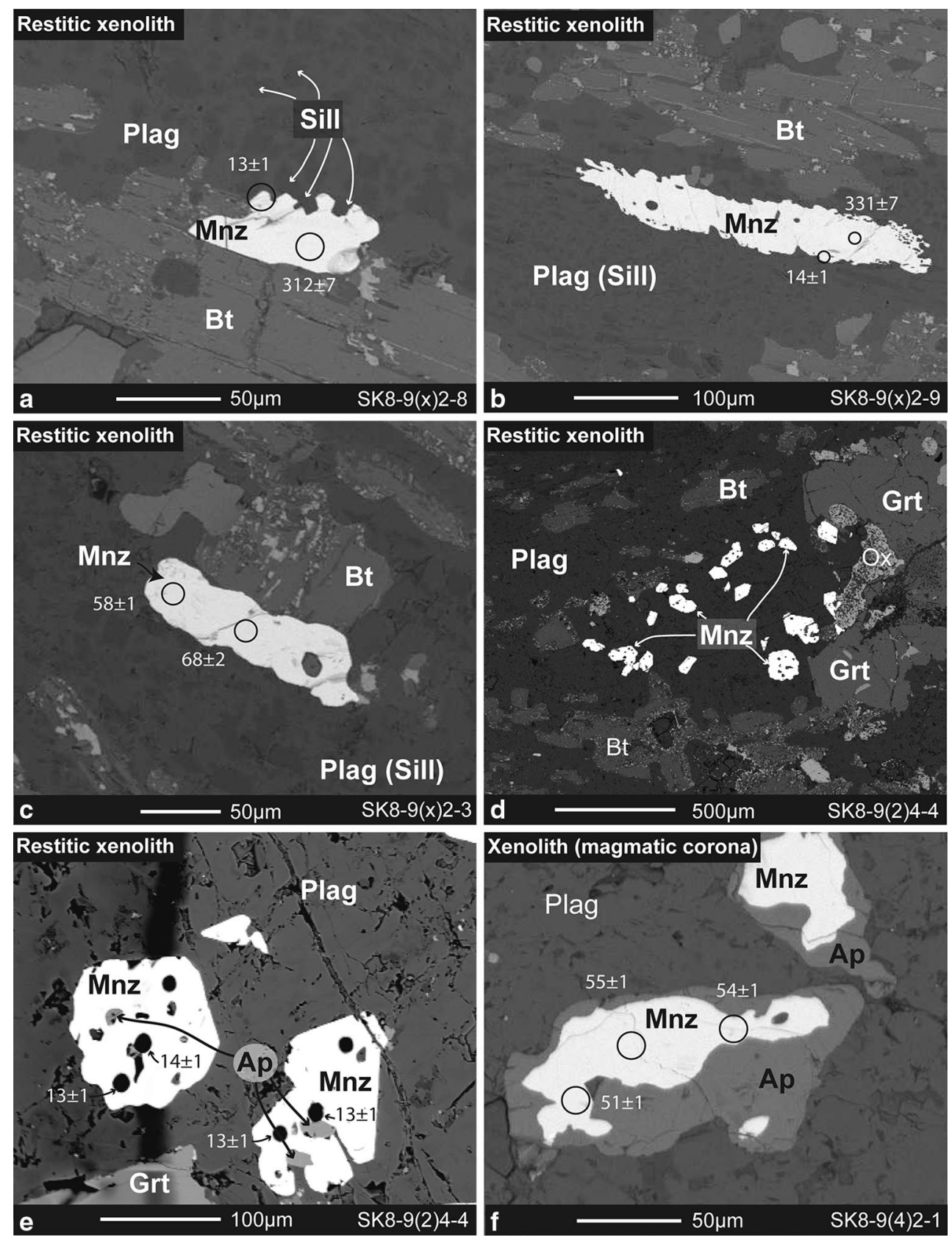

Fig. 5 BSE images of monazite grains. Monazite located in the restitic xenolith is associated with biotite and plagioclase $(\mathbf{a}-\mathbf{c})$. Some grains are in clusters (d) sometimes associated with tiny grains of

apatite (e). Monazite located in the magmatic corona is surrounded by apatite (f). Circles show the location of LA-ICP-MS pits $(11 \mu \mathrm{m}$ diameter) and their corresponding ${ }^{208} \mathrm{~Pb} /{ }^{232} \mathrm{Th}$ ages in $\mathrm{Ma}(2 \sigma$ level)

low $\mathrm{Lu} / \mathrm{Sr}$ ratio and a negative $\mathrm{Eu}$ anomaly $\left(\mathrm{Eu}_{\mathrm{N}} / \mathrm{Eu}^{*}\right)$ of $\sim 0.30$ (Fig. 4c). The HREE content is highly variable between grains but is homogeneous within a single grain (Fig. 4c). The highest HREE contents are observed in the monazites surrounded by apatite in the magmatic corona.

Fig. 6 Monazite A. a EMP maps of Y, La, Th, Ca and sketch of the whole grain of monazite A. Dashed squares in sketches correspond to NanoSIMS map locations. b, c NanoSIMS distribution maps $\left({ }^{89} \mathrm{Y}\right.$, ${ }^{139} \mathrm{La},{ }^{238} \mathrm{U},{ }^{208} \mathrm{~Pb},{ }^{232} \mathrm{Th}$ and ${ }^{208} \mathrm{~Pb} /{ }^{232} \mathrm{Th}$ ), RGB maps ( $\mathrm{Y}$ in red, Th in green and $\mathrm{U}$ in blue) and interpretive sketches of selected portions of monazite A. The arrow on the La map b shows zoning. The sketches distinguish between the M1 (red), M2 (green) and M3 (orange) domains 


\section{Monazite A (SK8-9(x)2-8)}
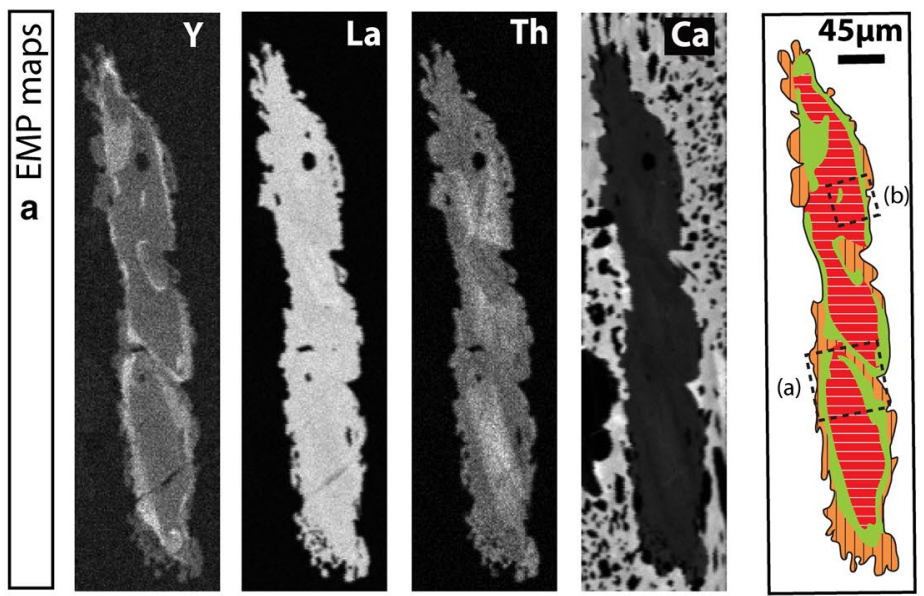

$\mathrm{M} 1$

b NanoSIMS maps

\section{c NanoSIMS maps}
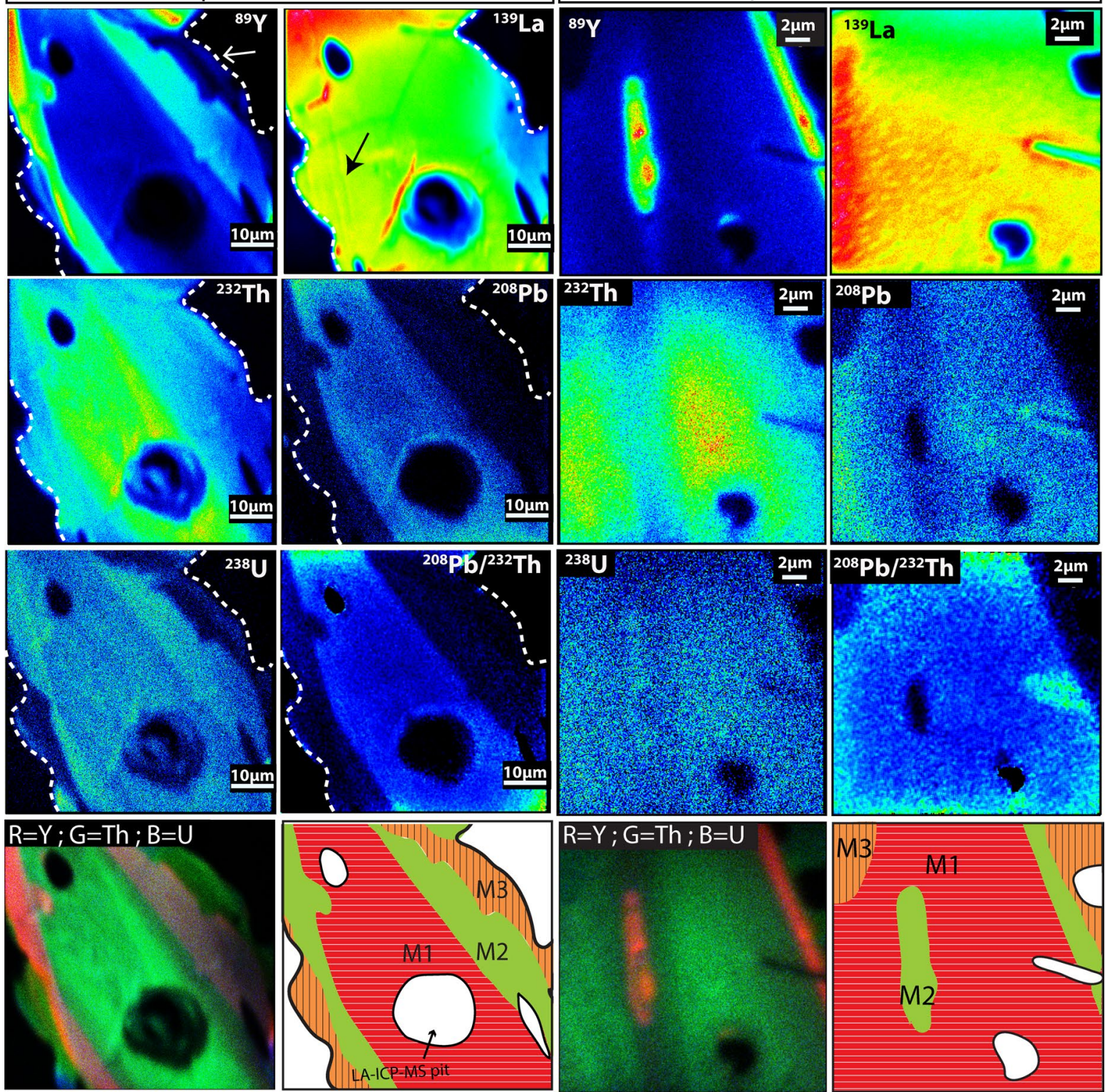
Fig. 7 Monazite B. a EMP maps of $\mathrm{Y}, \mathrm{La}, \mathrm{Th}, \mathrm{Ca}$ and interpretive sketch of the whole grain of monazite B. Dashed squares in sketches correspond to NanoSIMS map locations. b NanoSIMS distribution maps $\left({ }^{89} \mathrm{Y},{ }^{139} \mathrm{La},{ }^{238} \mathrm{U},{ }^{208} \mathrm{~Pb},{ }^{232} \mathrm{Th}\right.$ and ${ }^{208} \mathrm{~Pb} /{ }^{232} \mathrm{Th}$ ), RGB maps ( $\mathrm{Y}$ in red, Th in green and $\mathrm{U}$ in blue) and interpretive sketches of small parts of monazite B. The arrows show sub-domains in M3 domains
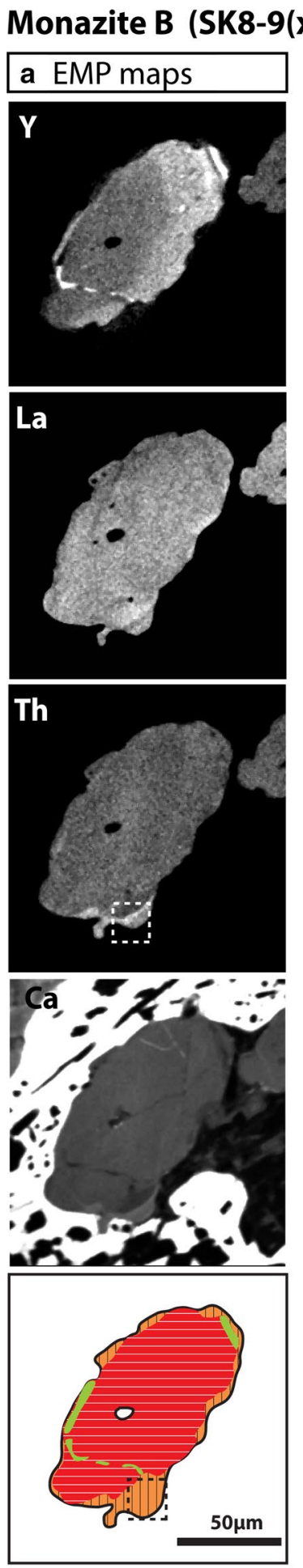
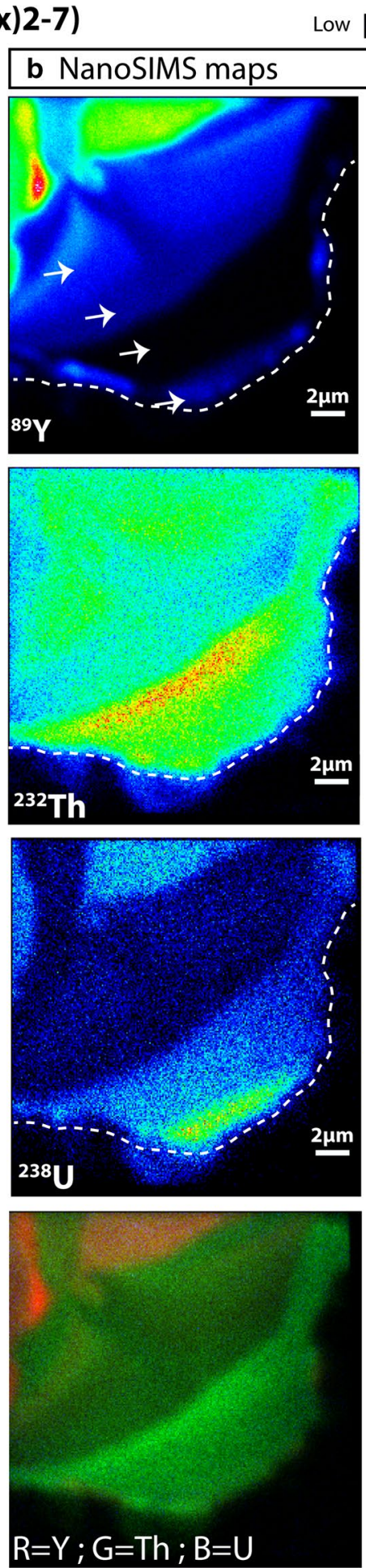
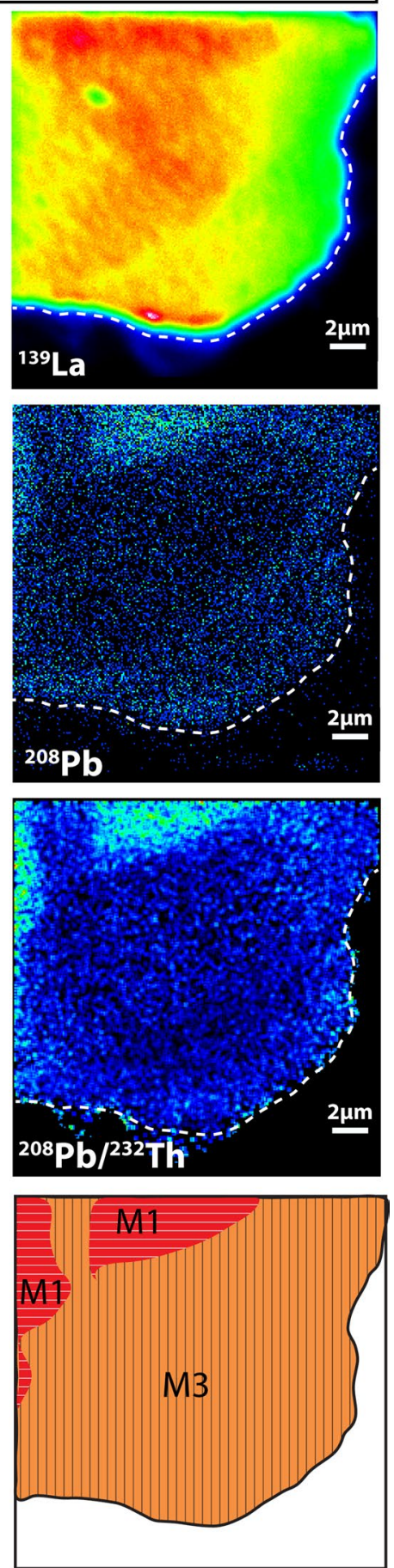

NanoSIMS images of the M1 domain are shown for monazites A, B and D (Figs. 6b, c, 7b, 9b). Sharp boundaries are displayed between the M1 domain and the other domains in $\mathrm{Th}, \mathrm{U}, \mathrm{Pb}$ and $\mathrm{Y}$ maps. In contrast, these boundaries are not observed in the La map, emphasizing that LREE variations are not correlated with the other elements (Fig. 6b). The La distribution commonly exhibits a mottled appearance with chemical variations at the $\mu \mathrm{m}$ scale (Figs. $6 \mathrm{c}, 7 \mathrm{~b}, 9 \mathrm{~b}$ ) that are not visible in the EMP maps. The distribution of $\mathrm{Y}, \mathrm{U}$ and $\mathrm{Pb}$ appears homogeneous at the sub- $\mu \mathrm{m}$ scale. 
Fig. 8 Monazite C. a EMP maps of $\mathrm{Y}, \mathrm{La}, \mathrm{Th}, \mathrm{Ca}$ and interpretive sketch of the whole grain of monazite C. Dashed squares in sketches correspond to NanoSIMS map locations. The arrows on Ca-map show minute Ca-enrichment. b NanoSIMS distribution maps $\left({ }^{89} \mathrm{Y}\right.$, ${ }^{139} \mathrm{La},{ }^{238} \mathrm{U},{ }^{208} \mathrm{~Pb},{ }^{232} \mathrm{Th}$ and ${ }^{208} \mathrm{~Pb} /{ }^{232} \mathrm{Th}$ ), RGB maps ( $\mathrm{Y}$ in red, Th in green and $\mathrm{U}$ in blue) and sketches of small parts of monazite C. The arrows show sub-domains in M3 domains
Monazite C (SK8-9(x)2-2')
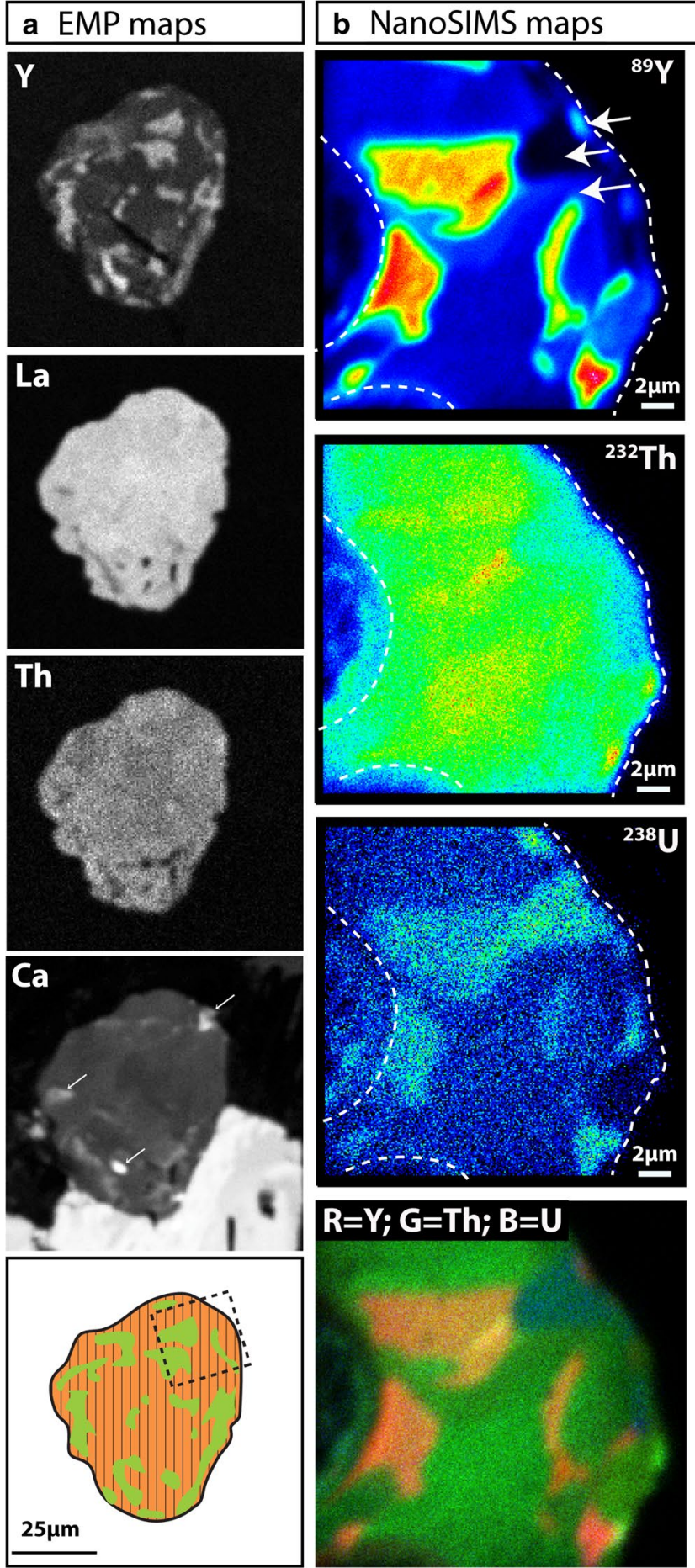
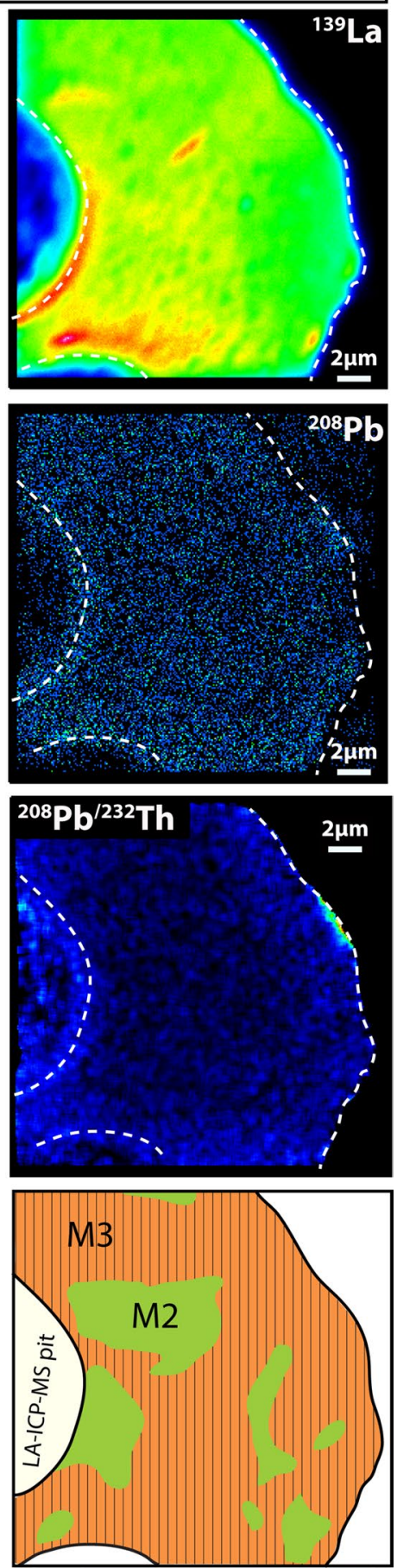

\section{The M2 domain}

The M2 domain occurs either as a narrow, internal rim surrounding the M1 domain (Fig. 6a) or as patches in the M3 domain (Fig. 8a). In the case of monazite B, the M2 rim is discontinuous and crosscuts the M1 domain, notably along micro-fractures (see Y map in Fig. 7a). The M2 domain has the same chemical composition as the M1 one (Table 1), except for Y, HREE, Sr and Eu (Table 2; Fig. 4c). Y is strongly enriched and variable (Table 2). Similar enrichment is observed for the HREE. In contrast, $\mathrm{Sr}$ and $\mathrm{Eu}$ are strongly depleted and the Eu anomaly is 0.08 (Fig. 4c).

NanoSIMS distribution maps for the M2 domain are shown for monazites A, C and D in Figs. $6 \mathrm{~b}, \mathrm{c}, 8 \mathrm{~b}$ and $9 \mathrm{~b}$ and reveal 
Fig. 9 Monazite D. a EMP maps of $\mathrm{Y}, \mathrm{La}, \mathrm{Th}, \mathrm{Ca}$ and interpretive sketches of the whole grain of monazite D. Dashed squares in sketches correspond to NanoSIMS map locations. $b$ NanoSIMS distribution maps ${ }^{89} \mathrm{Y},{ }^{139} \mathrm{La},{ }^{238} \mathrm{U},{ }^{208} \mathrm{~Pb},{ }^{232} \mathrm{Th}$ and ${ }^{208} \mathrm{~Pb} /{ }^{232} \mathrm{Th}$ ), RGB maps ( $\mathrm{Y}$ in red, $\mathrm{Th}$ in green and $\mathrm{U}$ in blue) and interpretive sketches of small parts of monazite D
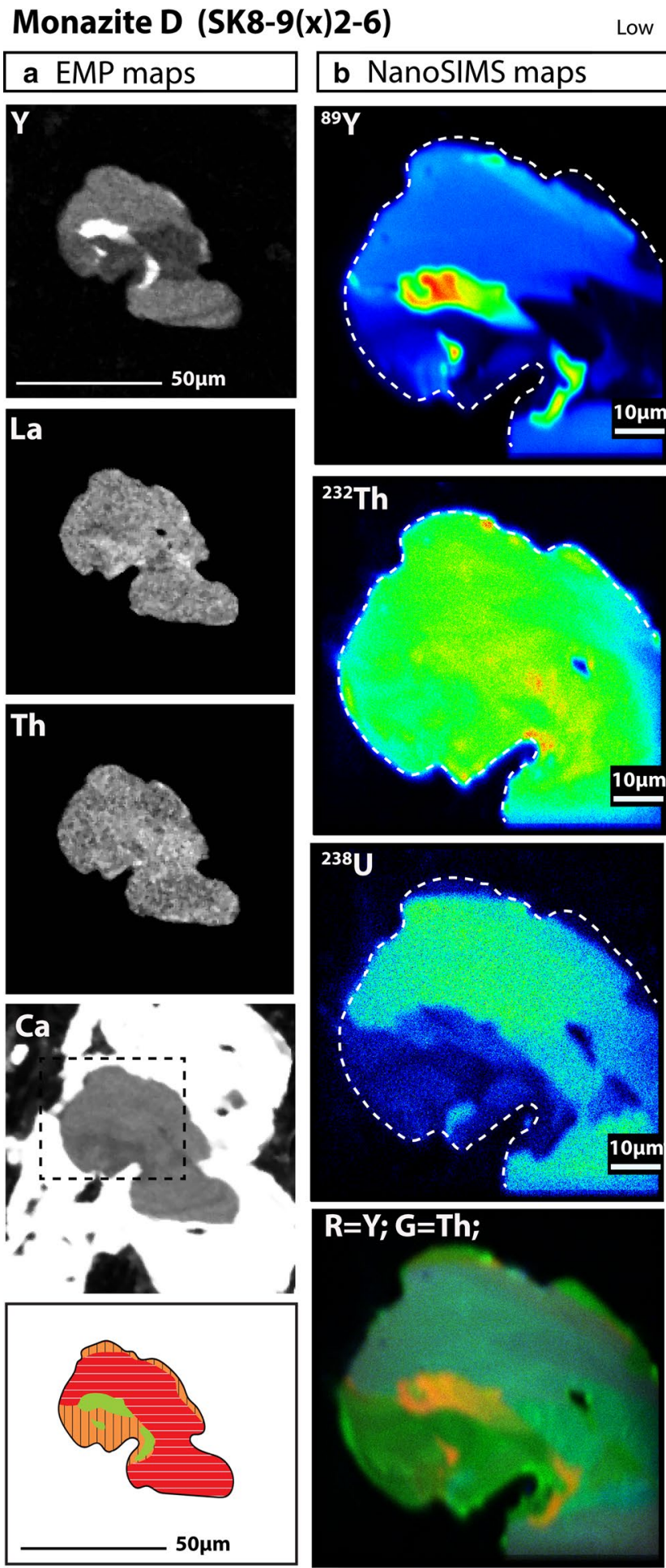

\section{b NanoSIMS maps}
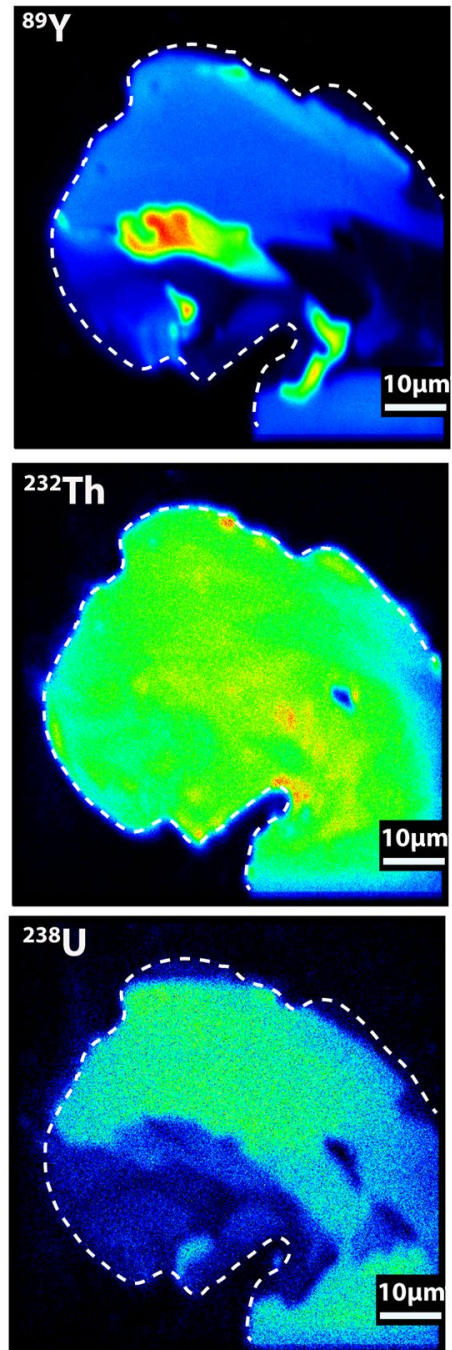
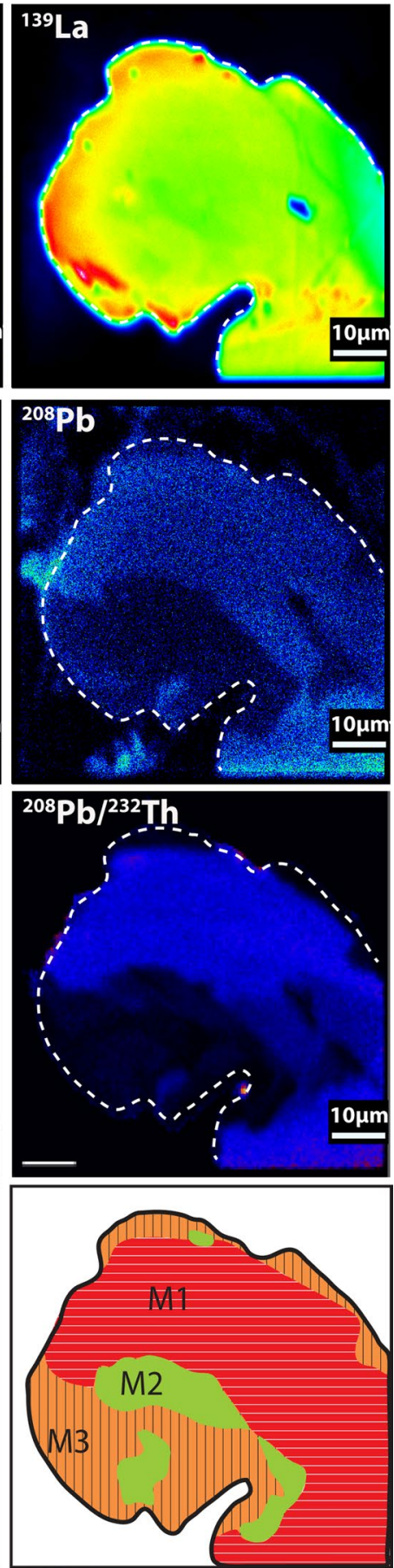

$\mathrm{U}$, Th and $\mathrm{Pb}$ chemical variations at small scale $(<\mu \mathrm{m})$ that were not identified by EMP analyses. The La maps display a mottled appearance (Figs. 6c, 8b) that is not correlated with the other domains. The $\mathrm{Th}$ and $\mathrm{Pb}$ distribution is homogeneous except in monazite $\mathrm{A}$. The $\mathrm{Y}$ and $\mathrm{U}$ distributions are positively correlated (Figs. 6b, 8b and to a lesser extent: 9b). Compared to the M1 domain, Th is depleted (Figs. 6b, c, 8b) or comparable in concentration (Fig. 9b) and $\mathrm{Pb}$ is consistently depleted. Finally, the M2 domain has a lower ${ }^{208} \mathrm{~Pb} /{ }^{232} \mathrm{Th}$ ratio than $\mathrm{M} 1$.

\section{The M3 domain}

The M3 domain occurs either as an external rim surrounding the M2 or M1 domain in the case of concentric zoning 
Table 1 Electron microprobe analyses (wt\%) of M1, M2 and M3 monazite domains from the magmatic corona and the restitic xenolith

\begin{tabular}{|c|c|c|c|c|c|c|c|c|c|}
\hline Sample & SK8-9(X)2 & SK8-9(X)2 & SK8-9(4)2 & SK8-9(2)4 & SK8-9(2)4 & SK8-9(X)2 & SK8-9(X)2 & SK8-9(X)2 & SK8-9(X)2 \\
\hline Analyse & 7 & 8 & 9 & 1 & 2 & 3 & 4 & 5 & 6 \\
\hline Location & Xenolith ss. & Xenolith ss. & Corona & Xenolith ss. & Xenolith ss. & Xenolith ss. & Xenolith ss. & Xenolith ss. & Xenolith ss. \\
\hline Domain & M1 & M1 & M1 & M2 & M2 & M2 & M3 & M3 & M3 \\
\hline $\mathrm{P}_{2} \mathrm{O}_{5}$ & 29.25 & 28.13 & 29.56 & 29.81 & 29.40 & 30.16 & 29.06 & 30.90 & 28.30 \\
\hline $\mathrm{CaO}$ & 1.26 & 1.27 & 1.59 & 0.72 & 0.57 & 1.32 & 1.48 & 1.58 & 1.89 \\
\hline $\mathrm{SiO}_{2}$ & 0.11 & 0.42 & 0.18 & 0.12 & 0.24 & 0.07 & 0.18 & 0.44 & 2.29 \\
\hline $\mathrm{Y}_{2} \mathrm{O}_{3}$ & 0.59 & 0.08 & 0.30 & 2.62 & 0.85 & 2.61 & 0.34 & 0.30 & 0.00 \\
\hline $\mathrm{La}_{2} \mathrm{O}_{3}$ & 14.71 & 14.47 & 16.79 & 14.32 & 15.72 & 14.43 & 14.71 & 14.12 & 13.41 \\
\hline $\mathrm{Ce}_{2} \mathrm{O}_{3}$ & 28.17 & 27.06 & 29.90 & 27.87 & 29.71 & 27.22 & 28.95 & 28.20 & 26.60 \\
\hline $\mathrm{Pr}_{2} \mathrm{O}_{3}$ & 2.94 & 3.33 & 3.17 & 3.14 & 3.06 & 2.98 & 3.16 & 3.21 & 3.23 \\
\hline $\mathrm{Nd}_{2} \mathrm{O}_{3}$ & 11.56 & 12.00 & 10.99 & 11.68 & 11.89 & 10.93 & 12.04 & 11.81 & 11.53 \\
\hline $\mathrm{Sm}_{2} \mathrm{O}_{3}$ & 2.08 & 2.04 & 1.43 & 1.69 & 1.82 & 1.61 & 1.57 & 1.74 & 1.15 \\
\hline $\mathrm{Gd}_{2} \mathrm{O}_{3}$ & 1.32 & 1.36 & 1.07 & 1.56 & 1.50 & 1.65 & 0.93 & 1.01 & 0.40 \\
\hline $\mathrm{PbO}$ & 0.01 & 0.14 & 0.02 & 0.00 & 0.00 & 0.00 & 0.00 & 0.00 & 0.04 \\
\hline $\mathrm{ThO}_{2}$ & 4.12 & 7.39 & 4.00 & 3.48 & 3.28 & 4.34 & 5.79 & 4.87 & 8.47 \\
\hline $\mathrm{UO}_{2}$ & 0.80 & 0.67 & 0.47 & 0.14 & 0.24 & 0.28 & 0.20 & 0.14 & 0.50 \\
\hline Total & 96.82 & 98.24 & 99.40 & 97.07 & 98.18 & 97.53 & 98.32 & 98.23 & 97.75 \\
\hline
\end{tabular}

(Figs. 6a, 7a), or, in the case of patchy zoning, as a large zone corresponding to the whole grain and containing small $(2-10 \mu \mathrm{m})$ M2 domains (Fig. 8a). The M3 domain is characterized by a strong $\mathrm{Y}$ depletion relative to the M2 domain, and a slightly lower or similar $\mathrm{Y}$ content relative to the M1 domain (Table 1). EMP Ca maps show local Ca enrichment in some M3 domains (Figs. 7a, 8a; Table 1) that are sometimes correlated with Th enrichment in monazite B (Fig. 7a). The M3 domain has a lower HREE content than the M2 domain and is similar to the maximum contents of the M1 domain (Fig. 6a; Table 2). Sr and Eu contents and the negative Eu anomaly (0.08) are comparable to those of the M2 domain (except for one analysis that gives a very high $\mathrm{Sr}$ content; Fig. 4c).

NanoSIMS images of the M3 domain are shown for monazites A, B, C and D in Figs. 6b, c, 7b, 8b and 9b. As for the M1 and M2 domains, La distribution maps display a mottled appearance (Figs. 6c, 8b) not correlated with the other elements. NanoSIMS maps show a heterogeneous $\mathrm{Y}$ distribution in the $\mathrm{M} 3$ domain which is not visible on the EMP maps. In monazites A, B, C and D, the M3 domain consists of small $(500 \mathrm{~nm}-5 \mu \mathrm{m})$ sub-domains of decreasing Y content from the core to the rim (Figs. 6b, c, $7 \mathrm{~b}, 8 \mathrm{~b})$. However, the external rim of the M3 domain may be enriched in $\mathrm{Y}(500 \mathrm{~nm}-1.5 \mu \mathrm{m})$ (Figs. $6 \mathrm{~b}, 7 \mathrm{~b}, 8 \mathrm{~b}-$ see arrows). The $U$ distribution is positively correlated with that of $\mathrm{Y}$, except in the $\mathrm{Y}$ depleted sub-domains in which $\mathrm{U}$ is strongly enriched (Figs. $7 \mathrm{~b}, 8 \mathrm{~b}$ ). The Th distribution is similar in M3 and M2 domains except for monazite B (Fig. 7b) where the Y depletion corresponds to a strong Th enrichment. ${ }^{208} \mathrm{~Pb} /{ }^{232} \mathrm{Th}$ is homogeneous in the $\mathrm{M} 3$ domain and similar to that of the M2 domain.

In summary, the xenolith monazite grains contain as many as three domains:

- M1 is Y, HREE poor and has a small negative Eu anomaly and high $\mathrm{Sr}$ content;

- M2 is Y, HREE rich and has a large negative Eu anomaly and low $\mathrm{Sr}$ content;

- M3 is Y, HREE poor, displays a large negative Eu anomaly and low Sr content, and may be Ca-enriched.

In these domains, Th, $\mathrm{U}$ (strongly correlated with $\mathrm{Y}$ ), $\mathrm{Pb}$ and $\mathrm{La}$ (not correlated with the other elements) distributions show sub- $\mu \mathrm{m}$ scale variations that are only identified by NanoSIMS imaging.

\section{U-Th-Pb dating}

In situ dating by LA-ICP-MS was performed in thin sections in the three monazite domains described above. Only concordant ${ }^{208} \mathrm{~Pb} /{ }^{232} \mathrm{Th}$ versus ${ }^{206} \mathrm{~Pb} /{ }^{238} \mathrm{U}$ data are considered and plotted in Figs. 10, 11, 12 and reported in Table 3.

Twenty-three analyses were performed in the M1 domain. Seven analyses define a discordia line in the Tera-Wasserburg diagram with a lower intercept age at $309 \pm 9 \mathrm{Ma}(\mathrm{MSWD}=2.2)$ (M1 domain-the oldest ages, Fig. 10). Fifteen analyses provide concordant and scattered ${ }^{208} \mathrm{~Pb} /{ }^{232} \mathrm{Th}$ and ${ }^{206} \mathrm{~Pb} /{ }^{238} \mathrm{U}$ ages from 43 to $70 \mathrm{Ma}$ (M1 


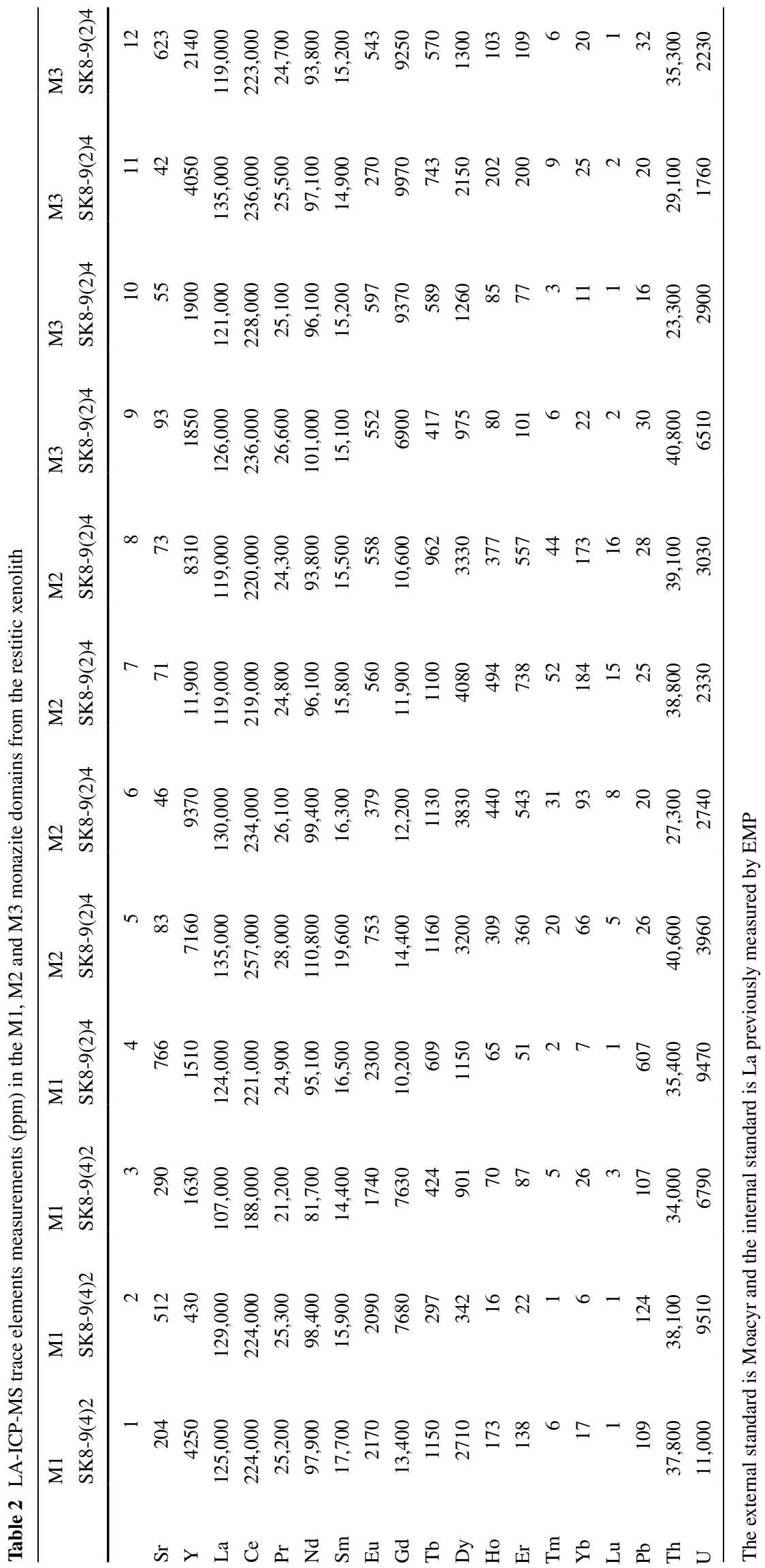




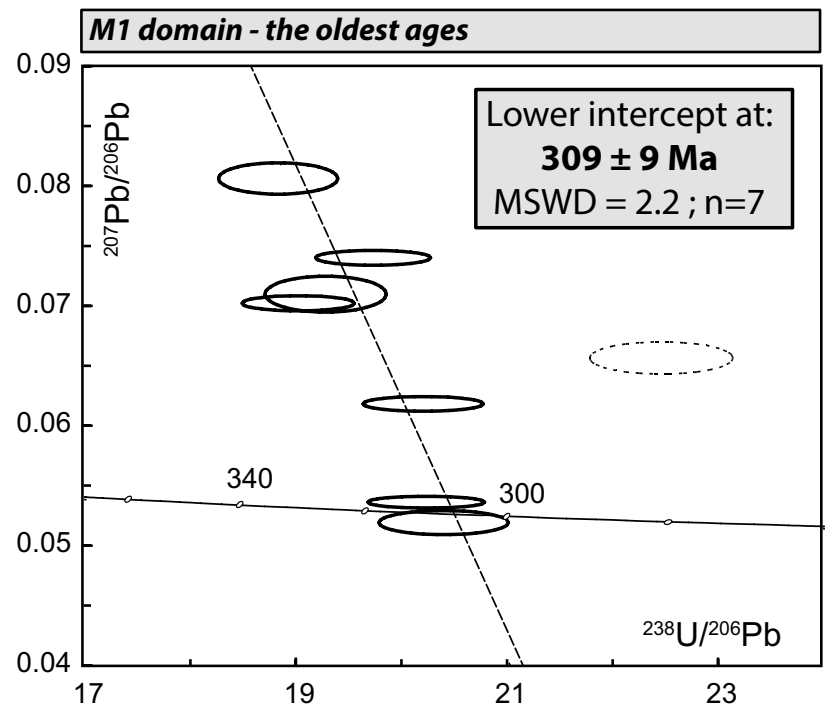

Fig. 10 Tera-Wasserburg diagram of the M1 monazite that yielded the oldest ages. The lower intercept age was calculated with the undashed ellipses

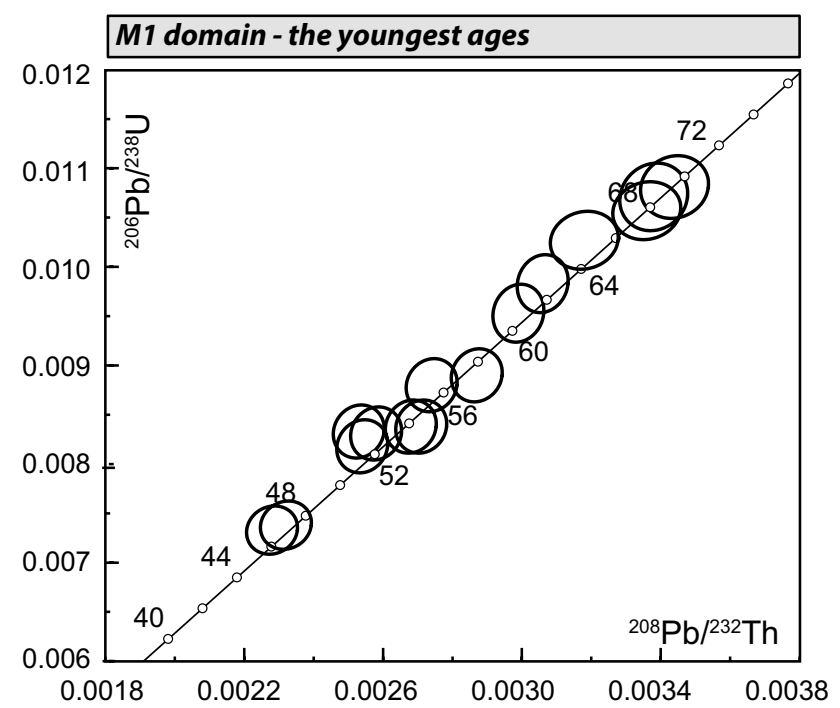

Fig. $11{ }^{206} \mathrm{~Pb} /{ }^{238} \mathrm{U}$ versus ${ }^{208} \mathrm{~Pb} /{ }^{232} \mathrm{Th}$ diagram of the M1 monazite that yielded the youngest ages. The U-Th-Pb ages are strongly scattered, ranging from $\sim 43$ to $\sim 70 \mathrm{Ma}$ and interpreted as mixing ages

domain - the youngest ages, Fig. 11), but discordant $\mathrm{U}-\mathrm{Pb}$ ages. In the M1 domain, the presence of two distinct ages is not correlated with chemical variations.

Sixteen analyses were performed in the M3 domain of eleven monazite grains (Fig. 12). The ${ }^{208} \mathrm{~Pb} /{ }^{232} \mathrm{Th}$ mean age is $13.1 \pm 0.1 \mathrm{Ma}(\mathrm{MSWD}=1.7 ; n=14)$. In a Tera-Wasserburg diagram, due to a very low ${ }^{207} \mathrm{~Pb}$ radiogenic content relative to the background signal, the analyses define a

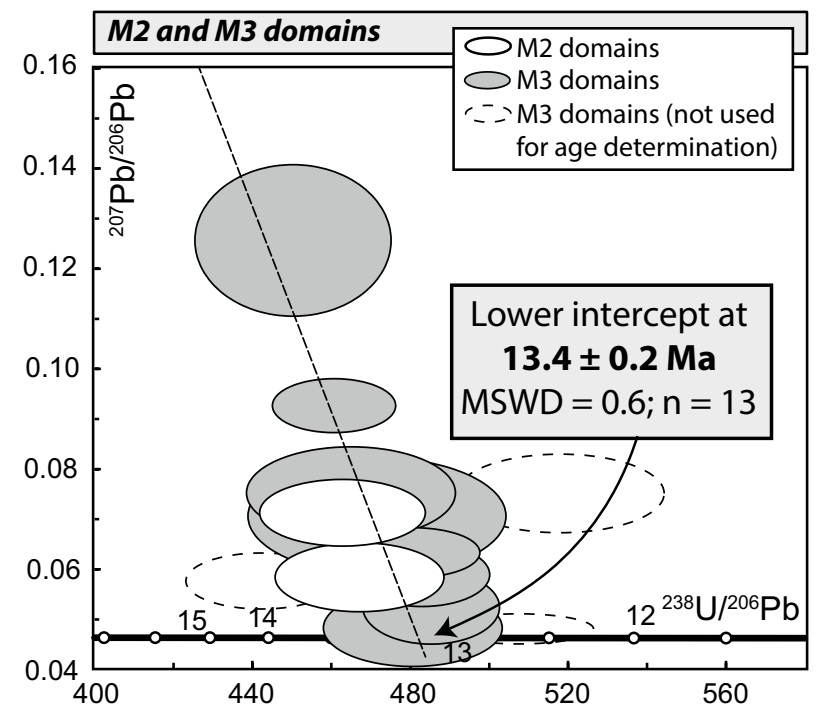

Fig. 12 Tera-Wasserburg diagram showing the M3 and M2 (two discordant data points) monazite domains. The lower intercept age was calculated with the undashed ellipses

linear trend (Fig. 12) that intercepts the concordia curve at $13.4 \pm 0.2 \mathrm{Ma}(\mathrm{MSWD}=0.6)$.

Because M2 is a narrow rim smaller than the spot size $(11 \mu \mathrm{m})$, it was not possible to date this domain precisely. Only two analyses are reported in Fig. 12 and coincide with the linear trend defined by the M3 domain in the Tera-Wasserburg diagram.

\section{Discussion}

\section{Monazite ages significance}

LA-ICP-MS dating of the M3 domain provides an age of $13.4 \pm 0.2 \mathrm{Ma}$, consistent with the age of $13.3 \pm 0.2 \mathrm{Ma}$ determined on zircons shielded within garnets from the same andesite (Bouloton and Paquette 2014). Because of its small size, the M2 domain could not be accurately dated. However, ${ }^{208} \mathrm{~Pb} /{ }^{232} \mathrm{Th}$ maps obtained by NanoSIMS imaging correspond to the age distribution map and allow for comparison of ${ }^{208} \mathrm{~Pb} /{ }^{232} \mathrm{Th}$ ratios among the different domains. ${ }^{208} \mathrm{~Pb} /{ }^{232} \mathrm{Th}$ maps in the M2 and M3 domains display very similar ${ }^{208} \mathrm{~Pb} /{ }^{232} \mathrm{Th}$ ratios (Figs. $6 \mathrm{~b}, \mathrm{c}, 7 \mathrm{~b}, 8 \mathrm{~b}$, $9 \mathrm{~b})$ and are therefore likely the same age at around $13 \mathrm{Ma}$. In the following discussion, the chemical characteristics of the M2 domain are used to strengthen this qualitative argument.

In the M1 domain, two age groups were obtained at $309 \pm 9 \mathrm{Ma}$ (Fig. 10) and between 43 and $70 \mathrm{Ma}$ (Fig. 11). The first age is consistent with the age of Variscan granite 
Table 3 U-Th-Pb ages of M1, M2 and M3 monazite domains

\begin{tabular}{|c|c|c|c|c|c|c|c|c|c|c|c|c|c|}
\hline \multirow[t]{2}{*}{ Samples } & \multirow[t]{2}{*}{ Domain } & \multicolumn{2}{|c|}{ Isotopic ratios } & \multicolumn{2}{|l|}{ Ages (Ma) } & \multicolumn{2}{|c|}{ Isotopic ratios } & \multicolumn{2}{|l|}{ Ages (Ma) } & \multicolumn{2}{|c|}{ Isotopic ratios } & \multicolumn{2}{|l|}{ Ages (Ma) } \\
\hline & & ${ }^{208} \mathrm{~Pb} /{ }^{232} \mathrm{Th}$ & $2 \sigma(\%)$ & ${ }^{208} \mathrm{~Pb} /{ }^{232} \mathrm{Th}$ & $2 \sigma$ & ${ }^{206} \mathrm{~Pb} /{ }^{238} \mathrm{U}$ & $2 \sigma(\%)$ & ${ }^{206} \mathrm{~Pb} /{ }^{238} \mathrm{U}$ & $2 \sigma$ & ${ }^{207} \mathrm{~Pb} /{ }^{235} \mathrm{U}$ & $2 \sigma(\%)$ & ${ }^{207} \mathrm{~Pb} /{ }^{235} \mathrm{U}$ & $2 \sigma$ \\
\hline SK89X2 & M1 & 0.0145 & 2.2 & 290 & 6 & 0.0445 & 2.5 & 281 & 7 & 0.403 & 3 & 344 & 9 \\
\hline SK89X2 & M1 & 0.0156 & 2.2 & 312 & 7 & 0.0490 & 2.4 & 309 & 7 & 0.351 & 3 & 305 & 8 \\
\hline SK89X2 & M1 & 0.0165 & 2.2 & 331 & 7 & 0.0531 & 2.4 & 334 & 8 & 0.590 & 3 & 471 & 11 \\
\hline SK8924 & M1 & 0.0152 & 2.2 & 305 & 7 & 0.0495 & 2.3 & 311 & 7 & 0.422 & 2 & 357 & 7 \\
\hline SK8924 & M1 & 0.0164 & 2.2 & 328 & 7 & 0.0526 & 2.3 & 330 & 7 & 0.509 & 2 & 418 & 8 \\
\hline SK8924 & M1 & 0.0159 & 2.1 & 319 & 7 & 0.0507 & 2.2 & 319 & 7 & 0.517 & 2 & 423 & 8 \\
\hline SK8924 & M1 & 0.0154 & 2.2 & 308 & 7 & 0.0494 & 2.2 & 311 & 7 & 0.365 & 2 & 316 & 6 \\
\hline SK89X2 & M1 & 0.0161 & 2.2 & 323 & 7 & 0.0519 & 2.4 & 326 & 8 & 0.508 & 3 & 417 & 10 \\
\hline SK89X2 & M1 & 0.0034 & 2.4 & 68 & 2 & 0.0107 & 2.6 & 69 & 2 & 0.087 & 3 & 84 & 2 \\
\hline SK89X2 & M1 & 0.0029 & 2.1 & 58 & 1 & 0.0089 & 2.5 & 57 & 1 & 0.067 & 3 & 66 & 2 \\
\hline SK89X2 & M1 & 0.0031 & 2.0 & 62 & 1 & 0.0098 & 2.4 & 63 & 2 & 0.080 & 3 & 79 & 2 \\
\hline SK8942 & M1 & 0.0025 & 2.4 & 51 & 1 & 0.0083 & 2.6 & 54 & 1 & 0.062 & 3 & 61 & 2 \\
\hline SK8942 & M1 & 0.0027 & 2.2 & 55 & 1 & 0.0084 & 2.6 & 54 & 1 & 0.063 & 3 & 62 & 2 \\
\hline SK8942 & M1 & 0.0027 & 2.2 & 54 & 1 & 0.0084 & 2.6 & 54 & 1 & 0.065 & 3 & 64 & 2 \\
\hline SK8942 & M1 & 0.0023 & 2.6 & 47 & 1 & 0.0074 & 2.7 & 47 & 1 & 0.060 & 3 & 60 & 2 \\
\hline SK8942 & M1 & 0.0030 & 2.0 & 60 & 1 & 0.0095 & 2.5 & 61 & 2 & 0.073 & 3 & 71 & 2 \\
\hline SK8942 & M1 & 0.0034 & 2.4 & 68 & 2 & 0.0107 & 2.6 & 69 & 2 & 0.082 & 3 & 80 & 2 \\
\hline SK8924 & M1 & 0.0027 & 2.2 & 55 & 1 & 0.0088 & 2.5 & 57 & 1 & 0.071 & 4 & 70 & 3 \\
\hline SK8924 & M1 & 0.0034 & 2.4 & 68 & 2 & 0.0106 & 2.3 & 68 & 2 & 0.080 & 3 & 78 & 2 \\
\hline SK8924 & M1 & 0.0032 & 2.5 & 64 & 1 & 0.0103 & 2.3 & 66 & 2 & 0.083 & 3 & 81 & 2 \\
\hline SK8924 & M1 & 0.0034 & 2.3 & 69 & 2 & 0.0108 & 2.4 & 69 & 2 & 0.089 & 3 & 87 & 2 \\
\hline SK89X2 & M1 & 0.0023 & 2.6 & 46 & 1 & 0.0073 & 2.7 & 47 & 1 & 0.059 & 3 & 58 & 2 \\
\hline SK89X2 & M1 & 0.0026 & 2.3 & 52 & 1 & 0.0083 & 2.6 & 53 & 1 & 0.064 & 3 & 63 & 2 \\
\hline SK89X2 & M1 & 0.0025 & 2.4 & 51 & 1 & 0.0082 & 2.7 & 53 & 1 & 0.063 & 3 & 62 & 2 \\
\hline SK89X2 & M2 & 0.0007 & 3.1 & 13 & 0 & 0.0022 & 3.7 & 14 & 0 & 0.021 & 8 & 21 & 2 \\
\hline SK8924 & M2 & 0.0007 & 3.0 & 14 & 0 & 0.0021 & 2.8 & 14 & 0 & 0.016 & 7 & 17 & 1 \\
\hline SK89X2 & M3 & 0.0007 & 3.1 & 13 & 0 & 0.0021 & 5.7 & 14 & 1 & 0.021 & 15 & 21 & 3 \\
\hline SK8924 & M3 & 0.0006 & 3.1 & 13 & 0 & 0.0021 & 3.8 & 13 & 1 & 0.014 & 14 & 14 & 2 \\
\hline SK8924 & M3 & 0.0007 & 3.1 & 13 & 0 & 0.0021 & 3.7 & 14 & 0 & 0.022 & 10 & 23 & 2 \\
\hline SK8924 & M3 & 0.0007 & 3.0 & 13 & 0 & 0.0021 & 2.9 & 13 & 0 & 0.015 & 12 & 15 & 2 \\
\hline SK8924 & M3 & 0.0007 & 3.1 & 13 & 0 & 0.0021 & 2.9 & 13 & 0 & 0.017 & 9 & 17 & 2 \\
\hline SK8924 & M3 & 0.0007 & 3.0 & 13 & 0 & 0.0022 & 4.7 & 14 & 1 & 0.022 & 11 & 22 & 2 \\
\hline SK8924 & M3 & 0.0006 & 3.1 & 13 & 0 & 0.0021 & 2.9 & 13 & 0 & 0.018 & 7 & 18 & 1 \\
\hline SK8924 & M3 & 0.0007 & 3.1 & 13 & 0 & 0.0021 & 3.7 & 14 & 0 & 0.017 & 10 & 17 & 2 \\
\hline SK8924 & M3 & 0.0007 & 3.0 & 13 & 0 & 0.0022 & 3.7 & 14 & 0 & 0.021 & 8 & 21 & 2 \\
\hline SK8924 & M3 & 0.0007 & 2.9 & 14 & 0 & 0.0023 & 3.5 & 15 & 0 & 0.018 & 9 & 18 & 2 \\
\hline SK89X2 & M3 & 0.0007 & 3.0 & 13 & 0 & 0.0022 & 4.5 & 14 & 1 & 0.038 & 11 & 38 & 4 \\
\hline SK89X2 & M3 & 0.0007 & 2.8 & 14 & 0 & 0.0022 & 2.8 & 14 & 0 & 0.028 & 5 & 28 & 2 \\
\hline SK8924 & M3 & 0.0006 & 3.1 & 13 & 0 & 0.0019 & 4.1 & 12 & 0 & 0.020 & 9 & 20 & 2 \\
\hline SK8924 & M3 & 0.0006 & 3.2 & 13 & 0 & 0.0020 & 3.0 & 13 & 0 & 0.013 & 6 & 13 & 1 \\
\hline
\end{tabular}

emplacement in the Western Carpathians (305-335 Ma in Maluski et al. 1993). The M1 monazite dated at $309 \pm 9 \mathrm{Ma}$ is thus presumably related to this crustal-scale melting event. In this context, it is likely that the restitic nature of the xenolith results from melting during this regional event and predates the xenolith/andesite interaction.
The age group ranging from 43 to $70 \mathrm{Ma}$ is more difficult to interpret. Since these ages were obtained in the rim as well as in the core of the M1 domain, the age distribution does not provide any significant information that could aid in the interpretation. They could correspond to a long-term event affecting the gneissic rock between 


\section{a Gneiss before enclosing}
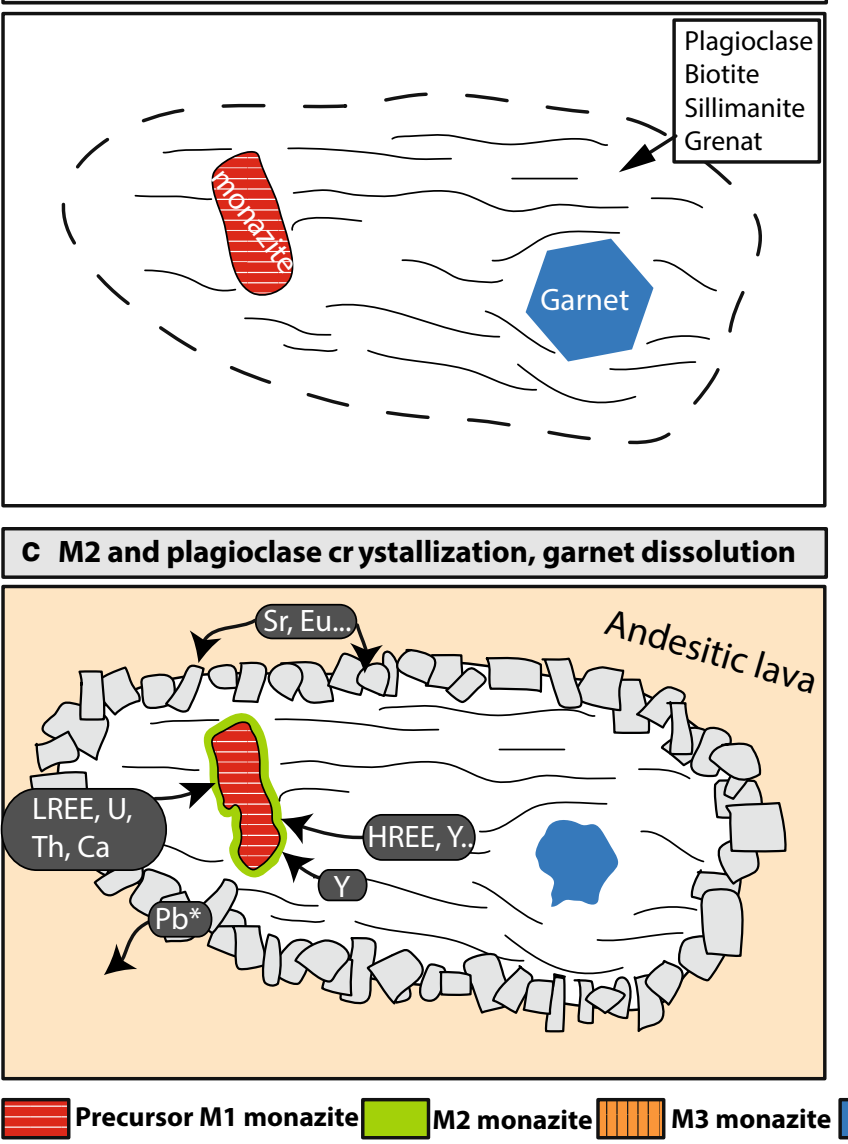

Fig. 13 Schematic summary of element transfers among monazite, garnet and plagioclase during the xenolith/andesite interaction. a The peraluminous rock before the interaction contains the M1 monazite. b At $13 \mathrm{Ma}$, the peraluminous rock is enclosed in an andesitic lava. A plagioclase-bearing magmatic corona crystallizes around the xenolith. The M1 monazite and metamorphic garnets are dissolved. Sr and $\mathrm{Eu}$ are preferentially reincorporated in plagioclase. c The M2 mona-

70 and $40 \mathrm{Ma}$. In the studied area, such event is poorly documented; only Maluski et al. (1993) report ${ }^{40} \mathrm{Ar}-{ }^{39} \mathrm{Ar}$ ages at circa $65 \mathrm{Ma}$ in deformed granites, interpreted as the result of mylonitization during stacking, thrusting and following exhumation of different units during Alpine tectonothermal events. These low-temperature and longterm processes are typically associated with fluid circulation that can be easily recorded by monazite (Bosse et al. 2009; Kelly et al. 2012). However, no chemical, textural or petrological evidences support this interpretation in our samples. It is thus more likely that these ages could correspond to mixing ages between the $\mathrm{M} 1$ and the youngest M2/M3 domains. In any case, the M1 monazite crystallized before the xenolith/lava interaction and corresponds to a precursor phase for the crystallization of the M2 and M3 domains.

\section{M1 and garnet dissolution, plagioclase cr ystallization}
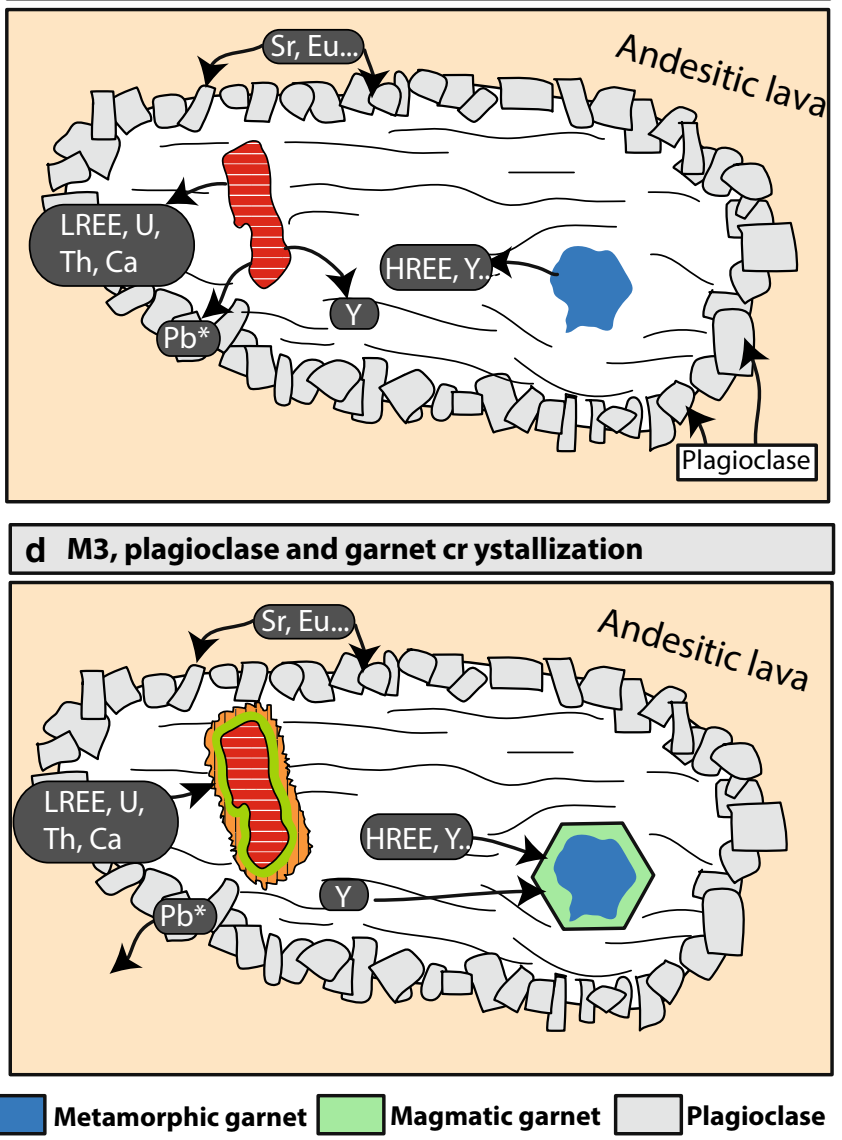

zite crystallizes from the elements released by the M1 monazite and from the $\mathrm{Y}$ and HREE released by metamorphic garnet. Because $\mathrm{Sr}$ and $\mathrm{Eu}$ are preferentially incorporated in plagioclase, M2 monazite is depleted in these elements relative to the M1 monazite. d The M3 monazite and the magmatic garnet crystallize. The M3 monazite is Y- and HREE-depleted relative to the M2 domain because these elements are preferentially incorporated in garnet rather than in monazite

\section{Monazite chemical behaviour during xenolith/andesite interaction}

\section{Element mobility and trace element partitioning between monazite, garnet and plagioclase}

Three successive crystallization domains (M1, M2, M3) are observed in the monazite. Their chemical compositions reflect interaction with the other rock-forming phases and, in turn, the mineralogical reactions recorded by monazite. Moreover, the coexistence of M3 monazite with magmatic garnet rim and plagioclase allows the calculation of partition coefficients between those minerals for the considered trace elements. In the absence of petrographic evidence, these can be of great help to determine whether minerals crystallized in equilibrium and link the age recorded by 
Table 4 Trace elements distribution coefficients between monazite and garnet published in Hermann and Rubatto (2003) (Mnz/Grt*), the M3 monazite and the magmatic garnet rim (M3/Grt rim); the M3 monazite and the plagioclase from the external corona (M3/Plag); the plagioclase from the external corona and the magmatic garnet rim (Plag/Grt rim)

\begin{tabular}{lllrl}
\hline Trace element & Mnz/Grt* & M3/Grt rim & M3/Plag & Plag/Grt rim \\
\hline $\mathrm{La}$ & $25,700,000$ & $1,950,000$ & 8150 & 240 \\
$\mathrm{Ce}$ & $18,400,000$ & 622,000 & 8340 & 75 \\
$\mathrm{Pr}$ & $3,600,000$ & 157,000 & 11,300 & 14 \\
$\mathrm{Nd}$ & 417,000 & 37,200 & 16,400 & 2.3 \\
$\mathrm{Sm}$ & 18,900 & 3370 & 23,400 & 0.14 \\
$\mathrm{Eu}$ & 13,600 & 350 & 560 & 0.62 \\
$\mathrm{Gd}$ & 2720 & 680 & 21,800 & 0.03 \\
$\mathrm{~Tb}$ & 546 & 200 & 7820 & 0.03 \\
$\mathrm{Dy}$ & 149 & 67 & 670 & 0.10 \\
$\mathrm{Y}$ & 46 & 18 & 7550 & 0.00 \\
$\mathrm{Ho}$ & 53 & 24 & 1930 & 0.01 \\
$\mathrm{Er}$ & 23 & 8.5 & 570 & 0.01 \\
$\mathrm{Tm}$ & 11 & 2.7 & 140 & 0.02 \\
$\mathrm{Yb}$ & 5.3 & 1.1 & 69 & 0.02 \\
$\mathrm{Lu}$ & 2.9 & 0.5 & 30 & 0.02 \\
$\mathrm{Th}$ & $3,090,000$ & 610,000 & 10,094 & 60.3 \\
$\mathrm{U}$ & 276,000 & 62,000 & 1638 & 38.1 \\
\hline
\end{tabular}

monazite to the mineralogical reactions affecting the hostrock (Fig. 4d).

Because evidence for the early petrological evolution of the primary gneissic rock is scarce, we cannot recover the conditions of crystallization of the M1 domain. Nevertheless, the small negative Eu anomaly and the low HREE content suggest monazite crystallization in the presence of plagioclase and garnet (Pyle and Spear 2003) (Fig. 4c).

As discussed above, the M2 monazite domain is characterized by strong $\mathrm{Y}$ and HREE enrichments and $\mathrm{Sr}$ and Eu depletions compared to the M1 domain (Fig. 4c). The Y and HREE enrichments require an external source. Given the mineralogy of the rock, garnet is the best candidate source for $\mathrm{Y}$ and HREE during M2 crystallization (Pyle and Spear 2003; Rubatto et al. 2013; Fig. 4a). The presence of a resorbed boundary between the core and the magmatic rim in garnet (Fig. 3) confirms that garnet was partially dissolved during the xenolith/andesite interaction, potentially providing $\mathrm{Y}$ and HREE to the M2 monazite. The low $\mathrm{Sr}$ content and the large negative Eu anomaly (Fig. 4c) imply that M2 growth occurred during plagioclase crystallization (Rubatto et al. 2013), in agreement with the presence of the plagioclase-bearing magmatic corona surrounding the whole xenolith.

The M3 monazite domain is characterized by a reduction in the $\mathrm{Y}$ and HREE content with respect to M2 (Fig. 4c). This suggests that unlike M2, the M3 domain crystallized during the growth of magmatic garnet. Indeed, $\mathrm{Y}$ and HREE are preferentially partitioned into garnet rather than monazite when these two phases crystallize simultaneously (Spear and Pyle 2002; Pyle and Spear 2003; Fig. 13d). This is confirmed by the partition coefficients determined between the M3 monazite, the magmatic garnet rim and the plagioclase (Fig. 4d). Hermann and Rubatto (2003) have already determined partition coefficients for monazite, garnet and zircon in metapelites during partial melting in the granulite facies conditions (Fig. 4d; Table 4). In our samples, Mnz/Grt partition coefficients display very similar patterns, albeit switched to lower values (up to one order of magnitude for the LREE and Eu). LREE are strongly partitioned into monazite relative to garnet and plagioclase, whereas partition coefficients for most of HREE, $\mathrm{Y}$ and $\mathrm{Eu}$ are much lower, yet above 1 (except for $\mathrm{Yb}$ and $\mathrm{Lu}$ ). LREE (La-Nd) and $\mathrm{Eu}$ are preferentially incorporated into plagioclase relative to garnet, while MREE and HREE show the reverse behaviour. As for the M2 monazite domain, the low $\mathrm{Sr}$ content and the large negative Eu anomaly demonstrate that the M3 monazite rim grew contemporaneously with plagioclase during the crystallization of the external magmatic corona from the xenolith. This is quite different when compared with garnets analysed by Hermann and Rubatto (2003), which crystallized during plagioclase breakdown and do not show any Eu anomaly (Fig. 4d).

In summary, the xenolith/andesite interaction has been recorded by newly formed M2 and M3 monazite domains that are both $13 \mathrm{Ma}$ in age (Fig. 13). The M2 domain records the dissolution of initial garnet (Fig. 13b, c), whereas the M3 domain records the crystallization of the magmatic garnet (Fig. 13d). Both domains record the crystallization of plagioclase in the corona (Fig. 13a-c). In the external magmatic corona of the xenolith, M2 and M3 domains are replaced by apatite because of the higher $\mathrm{Ca}$ activity in contact with plagioclase.

\section{Mechanisms for M2 and M3 domains growth}

NanoSIMS images of La display sub- $\mu$ m scale continuous zoning, lacking a sharp boundary between M2 and M3 domains, as observed in monazite A (Fig. 6b, arrow). This specific feature implies that the M2 and M3 crystallization results from the same continuous mechanism and that HREE, Y, Sr and Eu variations only reflect changes in the availability of these elements in the environment (owing to breakdown/crystallization of other rock-forming phases).

Crystallization of new monazite generations can result from mineralogical reactions and breakdown of P-, REEbearing minerals such as apatite, xenotime or allanite (Janots et al. 2008). But, in the absence of such primary minerals in both the xenolith and the andesite, the best candidate as a precursor phase is the monazite itself, more 
precisely the M1 monazite which can provide $\mathrm{P}$ and REE. At least two mechanisms may have contributed to M2 and M3 growth: coupled dissolution-precipitation (Putnis 2009) and grain coarsening by Ostwald ripening (Ayers et al. 1999). According to Putnis and Austrheim (2010) coupled dissolution-precipitation process occurs during the interaction between a fluid and a mineral: its dissolution results in an interfacial fluid, supersaturated in elements released by minerals, which may nucleate on the surface. This in situ mechanism induces the pseudomorphic replacement of an initial phase by the same phase of different composition, or the crystallization of an entirely new phase (Didier et al.2013; Seydoux-Guillaume et al. 2012). Ostwald ripening (Joesten 1991) results in the growth of large crystals at the expense of smaller ones by grain boundary diffusion resulting from minimization of the surface energy. Fluids and melt can enhance Ostwald ripening by dissolution of smaller grains and recrystallization of bigger grains with potentially different composition than the pre-existing grain (Ayers et al. 2003). In this case, dissolution and recrystallization are spatially and temporally disconnected, in contrast to coupled dissolution-precipitation processes. According to Ayers et al. (1999), Ostwald ripening can explain the complex chemical zoning observed in monazites. In this study, the replacement of M1 domain by M2, M3 or apatite (Fig. 5f) suggests that dissolution-precipitation may be the best candidate to explain monazite recrystallization.

In both cases, the medium enhancing dissolution of monazite can be a fluid or a melt (Putnis 2009; Ayers et al. 2003). According to the PT estimates of the xenolith/andesite interaction $\left(900-950{ }^{\circ} \mathrm{C}\right.$ and $\left.0.8-1.2 \mathrm{GPa}\right)$, the presence of a vapour phase is unlikely, as shown by the classical $\mathrm{P}-\mathrm{X} \mathrm{H}_{2} \mathrm{O}$ curve established by Hamilton et al. (1964): more than $13 \mathrm{wt} \%$ water would be needed to saturate the andesitic melt under $0.8 \mathrm{GPa}$ pressure. Consequently, melt appears as the best medium for the initiation of monazite dissolution and the transport of chemical elements in situ (for coupled dissolution-precipitation) or far away (for Ostwald ripening). Numerous studies have shown that monazite solubility is dependent upon the melt composition and its $\mathrm{H}_{2} \mathrm{O}$ content (Rapp and Watson 1986; Ellison and Hess 1988; Spear and Pyle 2002). Monazite solubility is greater in peralkaline melts than in meta- or peraluminous melts and increases with $\mathrm{H}_{2} \mathrm{O}$ and $\mathrm{Ca}$ contents in the melt. In our samples, magmatic garnet growth implies that the andesitic lava percolated in the core of the xenolith. Because of its high Ca content (up to $6 \mathrm{wt} \%$ ), the andesitic lava could easily enhance monazite dissolution in the xenolith and its subsequent recrystallization owing to local super-saturation. The presence of small grains of apatite included in the 13 Ma monazite crystals (Fig. 5e) and the minute $\mathrm{Ca}$ enrichment in the M3 domains (Fig. 8, white arrows in Ca-map) suggest that dissolution-precipitation was indeed initiated in the presence of Ca-rich melt. This proposes that the $\mathrm{Al} / \mathrm{Ca}$ ratio was high enough to enhance monazite recrystallization (Spear and Pyle 2002; Spear 2010) rather than apatite or allanite as expected with a Carich melt (Berger et al. 2009). Indeed, only one M1 monazite, located in the external corona, is partially replaced by apatite, maybe because of proximity with plagioclase.

\section{Contribution of the NanoSIMS imaging}

NanoSIMS imaging $\left({ }^{89} \mathrm{Y},{ }^{139} \mathrm{La},{ }^{208} \mathrm{~Pb},{ }^{232} \mathrm{Th}\right.$ and $\left.{ }^{238} \mathrm{U}\right)$ in the studied monazite results in the stacking of 20-30 linescans and is characterized by a spatial resolution of $100 \mathrm{~nm}$ and a lateral resolution (beam size) of $500 \mathrm{~nm}$, nearly an order of magnitude better than with the EMPA. This represents a significant information gain and allows for the identification of chemical and isotopic features that were not distinguishable by EMP element maps.

The high-quality Y map in the M3 domain of monazite B (Fig. 7b) allows for the identification of sub-domains $(500 \mathrm{~nm}-5 \mu \mathrm{m})$ and reflects the complexity of crystallization within the M3 domain. NanoSIMS imaging allowed the identification of trace element zoning such as $\mathrm{U}$ and $\mathrm{Pb}$, the latter being very depleted owing to the young monazite age (13 Ma) (monazites A, B, C and D in Figs. 6b, c, $7 \mathrm{~b}, 8 \mathrm{~b}, 9 \mathrm{~b})$. It was thus possible to correlate the distribution of these minor elements with the major ones at small scale (e.g. U and Y, monazite C). NanoSIMS also provides ${ }^{208} \mathrm{~Pb} /{ }^{232} \mathrm{Th}$ ratios images that are particularly useful for linking geochronology with distinct chemical domains.

In the present state of knowledge and in the context of the present study, it is not possible to interpret in detail the presence of zoning or small domains at the sub- $\mu \mathrm{m}$ scale $(<500 \mathrm{~nm})$. However, NanoSIMS mapping paired with in situ trace element and isotopic analyses could provide a powerful tool for improving the understanding of dissolution and crystallization processes in the monazite, and more generally in all minerals subject to these processes. In the future, analytical conditions will be enhanced in order to reduce the $\mathrm{O}$ beam size and consequently improve the lateral resolution.

\section{Conclusions}

This study reports the chemical and isotopic evolution of monazites from a restitic xenolith enclosed in a $\sim 13 \mathrm{Ma}$ andesitic lava. The xenolith/lava interaction is characterized by the growth of a plagioclase-bearing magmatic corona around the xenolith and the overgrowth of magmatic rims on partially resorbed metamorphic garnet. LAICP-MS trace element measurements and $\mathrm{U}-\mathrm{Th}-\mathrm{Pb}$ dating 
indicate variations of the HREE, Y, Eu and $\mathrm{Sr}$ contents in different generations of monazite that are correlated with the breakdown and/or growth of garnet and plagioclase. Three domains are distinguished:

- the M1 domain corresponds to the core of the monazite grains (low Y, HREE content and small negative Eu anomaly). Its age of $309 \pm 9$ Ma dates a regional Variscan hightemperature event associated with granite emplacement.

- the M2 domain grew during xenolith/lava interaction along with the external magmatic corona (large Eu anomaly) and the resorption of metamorphic garnet (low HREE and Y).

- the M3 domain crystallized at $13.1 \pm 0.1 \mathrm{Ma}$, the age of the andesitic lava, in the presence of the external magmatic corona (large Eu anomaly) and during magmatic garnet crystallization (low Y, HREE).

NanoSIMS images permit the isotopic and chemical differentiation of domains that were not distinguishable on $\mathrm{X}$-ray maps, especially for depleted elements such as $\mathrm{U}$ and $\mathrm{Pb} .{ }^{208} \mathrm{~Pb} /{ }^{232} \mathrm{Th}$ ratio maps offer the opportunity to directly correlate the ages with distinct chemical domains. This work demonstrates the importance of trace element studies in enhancing the reconstruction of the petrological history of monazite and the necessity of high-resolution tools such as NanoSIMS for improving the understanding of dissolution-crystallization processes.

Acknowledgments Thanks are due to Jean-Marc Hénot for his help in the use of SEM, Emily Mullen for English corrections and O. Laurent for fruitful discussion. The paper has been greatly improved by the critical and constructive comments of Alexander Stepanov and an anonymous reviewer. This work is supported a posteriori by CNRS-INSU.

\section{References}

Alonso-Perez R, Müntener O, Ulmer P (2009) Igneous garnet and amphibole fractionation in the roots of island arcs: experimental constraints on andesitic liquids. Contrib Mineral Petrol 157:541-558

Appel K, Appel P, Martinez-Criado G, Mocek B, Möller A (2010) Elemental nano-imaging of monazite and zircon using SR XRF. Acta Mineral Petrogr Abstr Ser 6:674

Ayers JC, Miller C, Gorisch B, Milleman J (1999) Textural development of monazite during high-grade metamorphism: hydrothermal growth kinetics, with implications for $\mathrm{U}$, Th- $\mathrm{Pb}$ geochronology. Am Mineral 84:1766-1780

Ayers JC, DelaCruz K, Miller C, Switzer O (2003) Experimental study of zircon coarsening in quartzite $\pm \mathrm{H} 2 \mathrm{O}$ at $1.0 \mathrm{GPA}$ and $1000{ }^{\circ} \mathrm{C}$, with implications for geochronological studies of highgrade metamorphism. Am Mineral 88:365-376

Berger A, Gnos E, Janots E, Fernandez A, Giese J (2008) Formation and composition of rhabdophane, bastnäsite and hydrated thorium minerals during alteration: implications for geochronology and low-temperature processes. Chem Geol 254:238-248
Berger A, Rosenberg C, Schaltegger U (2009) Stability and isotopic dating of monazite and allanite in partially molten rocks: examples from the Central Alps. Swiss J Geosci 102:15-29

Bingen B, Demaiffe D, Hertogen J (1996) Redistribution of rare earth elements, thorium, and uranium over accessory minerals in the course of amphibolite to granulite facies metamorphism: the role of apatite. Geochim Cosmochim Acta 60:1341-1354

Bohlen SR, Wall WJ, Boettcher AL (1983) Experimental investigation and application of garnet granulite equilibria. Contrib Mineral Petrol 83:52-61

Bosse V, Boulvais P, Gautier P, Tiepolo M, Ruffet G, Devidal JL, Cherneva Z, Gerdjikov I, Paquette JL (2009) Fluid-induced disturbance of the monazite $\mathrm{Th}-\mathrm{Pb}$ chronometer: in situ dating and element mapping in pegmatites from the Rhodope (Greece, Bulgaria). Chem Geol 261:286-302

Bouloton J, Paquette JL (2014) In situ U-Pb zircon geochronology of Neogen garnet-bearing lavas from Slovakia (Carpatho-Pannonian region, Central Europe). Lithos 184(187):17-26

Catlos EJ, Gilley LD, Harrison TM (2002) Interpretation of monazite ages obtained via in situ analysis. Chem Geol 188:193-215

Cherniak DJ, Watson BE, Grove M, Harrison TM (2004) Pb diffusion in monazite: a combined RBS/SIMS study. Geochim Cosmochim Acta 68:829-840

Crowley JL, Ghent ED (1999) An electron microprobe study of the $\mathrm{U}-\mathrm{Th}-\mathrm{Pb}$ systematics of metamorphosed monazite: the role of $\mathrm{Pb}$ diffusion versus overgrowth and recrystallization. Chem Geol 157:285-302

Cruz MJ, Cunha JC, Merlet C, Sabaté P (1996) Dataçao pontual das monazitas da regiao de Itambe, Bahia, através da microssonda electronica. XXXIX Congresso Brasileiro de Geologia, pp 206-209

Didier A, Bosse V, Boulvais P, Bouloton J, Paquette JL, Montel JM, Devidal JL (2013) Disturbance versus preservation of U-Th-Pb ages in monazite during fluid-rock interaction: textural, chemical and isotopic in situ study in microgranites (Velay Dome, France). Contrib Mineral Petrol 165:1051-1072

Didier A, Bosse V, Cherneva Z, Gautier P, Georgieva M, Paquette JL, Gerdjikov I (2014) Syn-deformation fluid-assisted growth of monazite during renewed high-grade metamorphism in metapelites of the Central Rhodope (Bulgaria, Greece). Chem Geol 381:206-222

Eggler DH (1972) Water-saturated and undersaturated melting relations in a Paricutin andesite and an estimate of water content in the natural magma. Contrib Mineral Petrol 34:261-271

Ellison AJG, Hess PC (1988) Peraluminous and peralkaline effects upon "monazite" solubility in high-silica liquids. EOS Trans 69:498

Erickson TM, Pearce MA, Cavosie AJ, Timms NE, Reddy SM, Taylor RJ, Clark C (2014) Resolving shock features in monazite using EBSD and their effects on SHRIMP U-Pb systematics. Goldschmidt 2014 conference abstract

Fletcher IR, McNaughton NJ, Davis WJ, Rasmussen B (2010) Matrix effects and calibration limitations in ion probe $\mathrm{U}-\mathrm{Pb}$ and $\mathrm{Th}-\mathrm{Pb}$ dating of monazite. Chem Geol 270:31-44

Foster G, Kinny P, Vance D, Prince C, Harris N (2000) The significance of monazite $\mathrm{U}-\mathrm{Th}-\mathrm{Pb}$ age data in metamorphic assemblages; a combined study of monazite and garnet chronometry. Earth Planet Sci Lett 181:237-340

Gardés E, Jaoul O, Montel JM, Seydoux-Guillaume AM, Wirth R (2006) $\mathrm{Pb}$ diffusion in monazite: an experimental study of interdiffusion. Geochim Cosmochim Acta 70:2325-2336

Gasquet D, Bertrand JM, Paquette JL, Lehmann J, Ratzov G, De Ascenc Guedes R, Tiepolo M, Boullier AM, Scaillet S, Nomade S (2010) Miocene to Messinian deformation and hydrothermalism in the Lauzière Massif (French Western Alps): new U-Th$\mathrm{Pb}$ and Argon ages. Bull Soc Géol Fr 181:227-241 
Gill JB (1981) Orogenic andesites and plate tectonics. Springer, Berlin

Hamilton DL, Burnham CW, Osborne E (1964) The solubility of water and effects of oxygen fugacity and water content on crystallization in mafic magmas. J Petrol 5:21-39

Harangi S, Downes H, Thirlwall M, Gmeling K (2007) Geochemistry, petrogenesis and geodynamic relationships of miocene calcalkaline volcanic rocks in the Western carpathian Arc, Eastern Central Europe. J Petrol 48:2261-2287

Hermann J, Rubatto D (2003) Relating zircon and monazite domains to garnet growth zones: age and duration of granulite facies metamorphism in the Val Malenco lower crust. J Metamorph Geol $21: 833-852$

Holland T, Blundy J (1994) Non-ideal interactions in calcic amphiboles and their bearing on amphibole-plagioclase thermometry. Contrib Mineral Petrol 116:433-447

Holland T, Powell R (2001) Calculation of phase relations involving haplogranitic melts using an internally consistent thermodynamic dataset. J Petrol 42:673-683

Janots E, Engi M, Berger A, Allaz J, Schwarz JO, Spandler C (2008) Prograde metamorphic sequence of REE minerals in politic rocks of the Central Alps: implications for allanite-monazitexenotime phase relations from 250 to $610{ }^{\circ} \mathrm{C}$. J Metam Geol 26:509-526

Jercinovic MJ, Williams ML, Allaz J, Donovan JJ (2011) Trace analysis in EMPA. European Workshop on Modern developments and applications in microbeam analysis. Anger, France

Joesten RL (1991) Kinetics of coarsening and diffusion-controlled mineral growth. In: Kerrick DM (ed) Contact metamorphism, 26. Reviews in Mineralogy, Mineralogical Society of America, Washington, DC, pp 507-582

Kelly NM, Harley SL, Möller A (2012) Complexity in the behavior and recrystallization of monazite during high-T metamorphism and fluid infiltration. Chem Geol 322-323:192-208

Konecny V, Lexa J, Hojstricova V (1995) The central Slovakia neogene volcanic field: a review. Acta Vulc 7:63-78

Konečný V, Bagdasarjan GP, Vass D (1969) Evolution of Neogene volcanism in Central Slovakia and its confrontation with absolute ages. Acta Geol Acad Sci Hung 13:245-258

Krenn E, Finger F (2007) Formation of monazite and rhabdophane at the expense of allanite during Alpine low temperature retrogression of metapelitic basement rocks from Crete, reece: microprobe data and geochronological implications. Lithos 95:130-147

Kriegsman LM, Hensen BJ (1998) Back reaction between restite and melt: implications for geothermobarometry and pressure-temperature paths. Geology 26:1111-1114

Maluski H, Rajlich P, Matte P (1993) ${ }^{40} \mathrm{Ar}-{ }^{39} \mathrm{Ar}$ dating of the Inner Carpathians Variscan basement and Alpine mylonitic overprinting. Tectonophysics 223:313-337

Moecher DP, Essene EJ, Anovitz LM (1988) Calculation and application of clinopyroxene-garnet-plagioclase-quartz geobarometers. Contrib Mineral Petrol 100:92-106

Montel JM, Foret S, Veschambre M, Nicollet C, Provost A (1996) Electron microprobe dating of monazite. Chem Geol 131:37-53

Paquette JL, Tiepolo M (2007) High resolution (5 $\mu \mathrm{m}) \mathrm{U}-\mathrm{Th}-\mathrm{Pb}$ isotope dating of monazite with excimer laser ablation (ELA)ICPMS. Chem Geol 240:222-237

Pécskay Z, Lexa J, Szakáca A, Seghedi I, Balogh K, Konečný V, Zelenka T, Kovacs M, Póka T, Fülöp A, Márton E, Panaiotu C, Cvetkovic V (2006) Geochronology of Neogene magmatism in the Carpathian arc and Intra-Carpathian area. Geol Carpath 57:511-530

Perkins D, Chipera SJ (1985) Garnet-orthopyroxene-plagioclasequartz barometry: refinement and application to the English
River subprovince and the Minnesota River valley. Contrib Mineral Petrol 89:69-80

Powell R, Holland TJ (1994) Optimal geothermometry and geobarometry. Am Mineral 79:120-133

Putnis A (2009) Mineral replacement reactions. Rev Mineral 70:87-124

Putnis A, Austrheim H (2010) Fluid-induced processes: metasomatism and metamorphism. Geofluids 10:254-269

Pyle J, Spear F (2003) Four generations of accessory-phase growth in low-pressure migmatites from SW New Hampshire. Am Mineral $88: 338-351$

Rapp RP, Watson EB (1986) Monazite solubility and dissolution kinetics: implications for the thorium and light rare earth chemistry of felsic magmas. Contrib Mineral Petrol 94:304-316

Rasmussen B, Fletcher IR, Muhling JR (2007) In situ U-Pb dating and element mapping of three generations of monazite: unravelling cryptic tectonothermal events in low-grade terranes. Geochim Cosmochim Acta 71:670-690

Rubatto D, Chakraborty S, Dasgupta S (2013) Timescales of crustal melting in the Higher Himalayan Crystallines (Sikkim, Eastern Himalaya) inferred from trace element-constrained monazite and zircon chronology. Contrib Mineral Petrol 165:349-372

Seghedi I (2010) Miocen-recent magmatism and geodynamic processes in the Carpathian-Pannonian region, relations with Balkan and Aegen region. XIX Congress of the Carpathian-Balkan geological association. Geol Balc 38(1-2):9-10

Seydoux-Guillaume AM, Paquette JL, Wiedenbeck M, Montel JM, Heinrich W (2002) Experimental resetting of the U-Th-Pb systems in monazite. Chem Geol 191:165-181

Seydoux-Guillaume AM, Goncalves P, Wirth R, Deutsch A (2003) Transmission electron microscope study of polyphase and discordant monazites: site-specific specimen preparation using the focused ion beam technique. Geology 31:973-976

Seydoux-Guillaume AM, Montel JM, Bingen B, Bosse V, de Parseval P, Paquette JL, Wirth R (2012) Low-temperature alteration of monazite: fluid mediated coupled dissolution-precipitation, irradiation damage, and disturbance of the $\mathrm{U}-\mathrm{Pb}$ and $\mathrm{Th}-\mathrm{Pb}$ chronometers. Chem Geol 330-331:140-158

Spear FS (2010) Monazite-allanite phase relations in metapelites. Chem Geol 279:55-62

Spear FS, Pyle JM (2002) Apatite, monazite, and xenotime in metamorphic rocks, reviews in mineralogy and geochemistry, phosphates: geochemical, geobiological, and materials importance. Rev Mineral 48:523-558

Szabó C, Harangi S, Csontos L (1992) Review of Neogene and Quaternary volcanism of the Carpathian-Pannonian region. Tectonophysics 208:243-256

Townsend KJ, Miller CF, D'Andrea JL, Ayers JC, Harrison TM, Coath CD (2001) Low temperature replacement of monazite in the Ireteba granite, Southern Nevada: geochronological implications. Chem Geol 172:95-112

Valley JW, Cavosie AJ, Ushikubo T, Reinhard DA, Lawrence DF, Larson DJ, Clifton PH, Kelly TF, Wilde SA, Moser DE, Spicuzza MJ (2014) Hadean age for a post-magma-ocean zircon confirmed by atom-probe tomography. Nat Geosci 7:219-223

van Achterberg E, Ryan CG, Jackson SE, Griffin W (2001) Data reduction software for LA-ICP-MS. In: Sylvester P (Ed.), Laser ablation-ICPMS in the Earth Science, vol 29. Mineralogical Association of Canada, pp 239-243

Zhu XK, O’Nions RK (1999) Zonation of monazite in metamorphic rocks and its implications for high temperature thermochronology: a case study from the Lewisian terrain. Earth Planet Sci Lett 171:209-220 